\title{
Female directors on the board and investment efficiency: evidence from Korea
}

\section{Young Zik Shin ${ }^{1}$ (D) Jeung-Yoon $\mathrm{Chang}^{2} \cdot \mathrm{Kyeongmin} \mathrm{Jeon}^{1} \cdot \mathrm{Hyunpyo} \mathrm{Kim}^{3}$}

Received: 31 July 2018 / Revised: 5 April 2019 / Accepted: 9 April 2019 / Published online: 26 April 2019

(C) The Author(s) 2019

\begin{abstract}
We investigate whether female board representation affects investment efficiency at Korean publicly traded companies from 2006 to 2014 . We find a positive association between female directorship and investment efficiency. For a subsample of firms that are classified into over- and under-investment groups, we find that the subsample of firms with female directors is less likely to over-invest compared to the group without female directors. This implies that female directors' risk-aversion, conservatism, and prudence affect investment efficiency by reducing over-investment rather than reducing under-investment. Other robustness tests corroborate our conclusion that female directors help to improve investment efficiency.
\end{abstract}

Keywords Female director - Corporate governance · Investment efficiency · Overinvestment

Young Zik Shin

romizigy@naver.com

Jeung-Yoon Chang

jenjychang@skku.edu

Kyeongmin Jeon

jkm8810@hanmail.net

Hyunpyo Kim

hkim@ship.edu

1 Institute of Management Research, Sungkyunkwan University, Seoul, Republic of Korea

2 SKK Business School, Sungkyunkwan University, Seoul, Republic of Korea

3 Accounting Management Information Systems Department, Shippensburg University of Pennsylvania, Shippensburg, USA 


\section{Introduction}

We investigate whether female directors serving on corporate boards are associated with investment efficiency in publicly traded firms in South Korea (hereafter, Korea). Investment efficiency is achieved when firms reduce either their levels of over- or under-investment. Hence, we ascertain the direction of improvement by examining whether the presence of female directors alters either over- or underinvestment decisions to improve the overall efficiency of investments and consider earlier work that documents differences in gender-related characteristics to explain this association.

Worldwide attention has been directed toward promoting women to corporate boards, and this has been one of the top issues discussed in corporate governance. In 2003, Norway was the first to initiate a gender quota with the objective of encouraging a greater proportion of board seats to be filled by female directors at public companies, with several other EU countries, such as France, Spain, Sweden, and Finland, following suit. More recently, California became the first state in the U.S. to require publicly traded companies to meet a gender quota and hire more women. Influential investors have taken note of gender diversity on boards as an important investing criterion, as corporate boards with more women tend to outperform those without such representation. Even the California Public Employees' Retirement System (CalPERS) has been an avid advocate of board diversity, acknowledging its positive impact on economic performance (CalPERS 2017). In relation to this, the 2016 MSCI reported that U.S. global companies with three female directors enjoyed a higher median ROE of $10.1 \%$ per annum versus $7.4 \%$ for those without such representation.

This ubiquitous movement across the globe to advance more women to corporate boardrooms is imposing a significant challenge to the current male-dominant boardrooms in Korea as well. Market participants and regulatory bodies are working to assign more board seats to female directors and are currently in the process of passing legislation on a gender quota requirement, affecting Korean firms. Korea is the fifteenth largest economy in the world and is a member country of the OECD (World Bank 2018). However, an entrenched patriarchy is the status quo, and male chauvinism is deep-rooted in the Korean business environment, which limits the opportunities of women to climb the corporate ladder by way of promotions. Even the 2019 Economist's Glass-Ceiling Index reports that Korea remains at the bottom of OECD countries in terms of workplace gender inequality, as has been the case for over the past seven consecutive years (The Economist, 2019). The unique chaebol-driven ownership structure also adds another layer of complexity because the chaebol business culture reinforces the old boy's network with regard to the already engrained male-dominant business culture that limits promotional opportunities for Korean businesswomen. Prior studies demonstrate that national cultural values affect the adoption of diversity management at organizations (Peretz et al. 2015) and further diversity and inclusion management efforts facilitate innovation (Stoermer et al. 2016). Although 
the challenge may be a strenuous one, our study demonstrates the potential benefits of recruiting female directors with respect to corporate investment decisions.

Empirical evidence abounds that gender plays an important role in the business context. Among the various theories, two competing theories attempt to explain why gender differences appear to have varying effects on business achievements. One is the liberal feminist theory, which assumes that women face greater discrimination and/or the systematic deprivation of resources, hindering their efforts to succeed in business ventures (Fischer et al. 1993). Hence, granted the same opportunities, women and men would achieve similar results due to similar capabilities (Holmes 2007). The other theory is social feminist theory, which recognizes inherent differences in gender that arise from the socialization process which shapes gender-related behaviors and outcomes. This difference does not imply that women are inferior to men but rather suggests that different traits can be equally effective (Black 1989; Carter et al. 2003; Fischer et al. 1993). Given that social feminist theory acknowledges gender-related traits, we put more weight on this view in conjunction with literature in the area of psychology that specifically delineates differences between men and women, as we believe differences in gender-based characteristics are relevant to the development of our hypotheses and that they will manifest differently in various business contexts.

In the realm of financial reporting, corporate governance, and investment decisions, a growing body of research provides evidence that gender affects various corporate outcomes. Some studies have reached the consensus that female directors are more independent than their male counterparts and that firm performance is higher for firms with more female board representation (Carter et al. 2003; Conyon and He 2017; Green and Homroy 2018; Liu et al. 2014). Female director assignments to audit committees improve their monitoring role, which in turn diminishes earnings management (Adams and Ferreira 2009; Gul et al. 2008). Their presence on boards also enhances stock price informativeness and improves earnings quality (Gul et al. 2011; Srinidhi et al. 2011). Moreover, firms with female directors make fewer acquisitions and pay lower bid premia, helping to create shareholder value (Levi et al. 2014), and higher dividends have been found at firms with weak governance which use dividends as a governance device (Chen et al. 2017). While gender diversity on top executive teams is associated with lower risk and better performance (Perryman et al. 2016), other studies do not find such a relationship and urge more research to understand the benefits in this area (Adams 2016; Sila et al. 2016). Other studies document the negative aspects of such appointments on firm risk, stock prices, and firm performance (Adams and Ferreira 2009; Ahern and Dittmar 2012; Matsa and Miller 2013). Thus far, research on this topic remains inconclusive and at best mixed.

This study focuses on Korean firms because much of the previous discussion draws on theories and data from advanced economies and cultures that generally advocate gender equality, which may not extend to the strong male-centered business environment in Korea. As noted above, the chaebol-driven business environment also sets Korea apart from other advanced economies, offering a unique context in which to explore how female participation at the board level affects investment decisions, as relatively less is known about how gender affects corporate decisions in 
Korea. Better board governance may not always be beneficial to the firm depending on the competition, as Ryu et al. (2017) find evidence that adjusted stock returns are lower for Korean firms with better governance when product market competition is intense.

We address our research question using a sample of 3748 firm-years across a nine-year period from 2006 to 2014. We start our investigation from 2006 to control for the regulatory effects of the Equal Employment Opportunity and Work Family Balance Assistance Act, which had undergone major revisions to encourage more employment of Korean women in the workplace. We manually collected female director information directly from public sources and used several investment efficiency models to test our question of whether women directors with board seats are associated with investment efficiency.

This study makes the following contributions. First, we extend the corporate governance literature on board characteristics using feminist theories, psychology, and the behavioral finance literature to explore the different implications of genderrelated characteristics on investment behavior. Further, we apply earlier theories to the Korean business environment, a market driven by a unique ownership structure (chaebols) that is markedly different from those in advanced western economies.

Second, our study comes at an opportune time and offers important policy implications to investors and regulatory bodies. The Korean government is in the process of legalizing a corporate gender quota in the private sector. Hence, our study further speaks to the recent discussion on mandating gender quota requirements.

The rest of this paper unfolds as follows. "Literature review and hypothesis development" section elaborates on the existing literature in the field of feminist theory, psychology, and behavioral finance to develop our hypothesis. "Sample and methodology" section presents the sample description and research design. The fourth section discusses the empirical results. "Conclusion" section summarizes the main results and concludes the study.

\section{Literature review and hypothesis development}

\section{Feminist theory, psychology, and behavioral finance}

Liberal feminist theory recognizes the systematic obstacles women face in society, impeding them from becoming successful managers (Fischer et al. 1993). Studies in this category argue that women are disadvantaged when attempting to gain appropriate funds, which hinders the full realization of potential firm performance (Carter and Rosa 1998; Marlow and Patton 2005). Other studies illustrate that women tend to underperform compared to their male counterparts due to differences in education and work experience, constraints on obtaining bank loans and human capital (e.g., networks), industry, and marital status (Bosma et al. 2004; Cooper et al. 1994; Du Rietz and Henrekson 2000; Klapper and Parker 2010). Strohmeyer et al. (2017) also find that the lower innovative breadth and depth levels at female-led firms were mainly due to reasons similar to those found in prior research. However, some studies criticize the lack of control of appropriate measures and argue that when male 
and female owners have similar characteristics and business traits, differences in profits disappear, implying that men and women are equally effective in managing a business given the same resources, including time (Arráiz 2018; Hundley 2001; Holmes 2007).

In contrast, social feminist theory acknowledges different gender-related behaviors and outcomes as part of the ongoing socialization process (Marlow and Patton 2005). This does not mean that women are inferior to men but rather suggests that different gender traits can be equally effective (Black 1989; Fischer et al. 1993). In relation to this, Booth and Nolen (2012) find that girls and boys were equally likely to choose risky outcomes depending on the educational environment and gender mix. Comparing management styles at large established firms, Mukhtar (2002) finds that female owners tend to practice greater delegation; gravitate toward a more participative, organizationally flatter management style; and operate their business in a similar fashion irrespective of size, whereas male managers tend to alter their managerial stance according to the size of their operation. However, McAdam (2013) criticized social feminist empiricism for simply comparing the performance outcomes of male and female entrepreneurs while not thoughtfully considering industry differences that depicted women as "underperforming" and presenting "women's ability to adapt to a male business world" as a problem to be solved. We rely on social feminist theory because we believe that distinct gender-based characteristics are relevant and will manifest differently in various business contexts. We further blend this school of thought with specific gender characteristics elaborated in psychology and behavioral finance to advance our hypothesis.

Consistent with the social feminist standpoint, the field of psychology has observed gender differences based on social, sexual, attitudinal, cognitive abilities, and on decision-making acumen. This line of research has reported that men and women act differently in various social and environmental contexts. Before the $1980 \mathrm{~s}$, gender studies that examined risk preferences in business decisions concluded and reinforced the traditional stereotypical images of women as relatively more prudent, less aggressive, weaker in leadership skills, and inferior in their problem-solving abilities. However, Johnson and Powell (1994) re-examined earlier research and refuted previous conclusions, contending that gender differences were no longer clear cut. Bajtelsmit and Bernasek (1996) further explain that gender differences with regard to risk tolerance levels and investment decisions arise not only due to inherent biological differences but also as a result of socialization with respect to income distribution, employment, and wealth accumulation. While some studies find that overconfident men are prone to engage in excessive trading and women are inclined to invest in risky assets when they expect returns to be high (Barber and Odean 2001; Han and Kim 2007), other studies find that women tend to trade more excessively and engage in more risk-taking activities than men in the financial sector (Berger et al. 2014; Byun 2005). As literature illustrates, men and women interact differently based on the environments and circumstances they encounter, and preconceived stereotypical images may also manifest differently in these instances, thus supporting the social feminist perspective.

Behavioral finance shares a similar view, demonstrating that women show varying traits in their financial decisions and preferences when making investments 
compared to men (Schumell 1996). Women tend to demand more information prior to making an investment and are more judicious in comprehending all details, whereas men tend to rely on one or two important informational cues that are critical to their investment decisions (Bajtelsmit and Bernasek 1996; Graham et al. 2002). Additionally, women are generally more conservative and risk-averse than men (Charness and Gneezy 2012; Cohn et al. 1975; Croson and Gneezy 2009; Eckel and Grossman 2008; Faccio et al. 2016; Owen and Temesvary 2018; Palvia et al. 2015; Powell and Ansic 1997; Riley and Chow 1992). Even female chief financial officers (CFOs) tend to be more prudent when issuing debt and tend to issue less debt compared to male CFOs (Barua et al. 2010; Huang and Kisgen 2013). Consistently, Faccio et al. (2016) document that firms with female CEOs have less debt; they also find that their firms have lower earnings volatility and higher survival potential than firms with male CEOs. However, Brinkhuis and Scholtens (2018) conclude that investors do not appear to discriminate between the two genders in CEO or CFO appointments. Geiler and Renneboog (2015) illustrate that men are twice as likely to participate in corporate tournaments because women face glass ceilings and promotion restrictions. Further, incentive packages tend to be more sensitive to performance for men than for women, partly due to greater risk-aversion levels (Kulich et al. 2011). Using Chinese data, Ng et al. (2016) find that female college students (i.e., called "wei-shangs") are risk-averse but argue that female characteristics helped them succeed as entrepreneurs. Mukarram et al. (2018) find that women directors have a positive effect on market performance for widely held high-tech firms but not for non-high-tech firms and family-controlled firms in India. Hence, distinct gender-related behaviors elicit varying outcomes.

\section{Investment efficiency}

Prior work on investment efficiency shows that a higher accounting quality level reduces information asymmetry between managers and the external providers of capital (Biddle and Hilary 2006) and increases investment efficiency (Biddle et al. 2009). Conversely, McNichols and Stubben (2008) find that firms subject to SEC investigations, firms sued by shareholders due to accounting misstatements, and firms with large discretionary accruals, traits all representing lower accounting quality, were associated with over-investment. Firms with weak internal control had lower investment efficiency as well (Cheng et al. 2013). Therefore, credible accounting information mitigates information asymmetry between firms and investors, allowing managers to reduce over- and/or under-investment and thus improve their investment efficiency. ${ }^{1}$ Alternatively, managers may over-invest in order to maintain their perquisites and engage in empire building, whereas managers may under-invest due to their tendency to avoid extreme risk. Consequently, investment efficiency is

\footnotetext{
1 Over-investment is defined as occurring when firms choose to invest in negative-net-present-value (NPV) projects and under-investment is defined as occurring when firms forego the opportunity to invest in positive-NPV projects.
} 
achieved when firms effectively mitigate the tendencies to either under- or overinvest, thereby bringing investments closer to the optimal levels.

Turning to the Korean market, Bae and Choi (2012) document that companies audited by an industry specialist and a Big 4 auditor were associated with lower levels of over-investment and under-investment compared to those that did not hire either type. In addition, Park and Kwon (2012) report that firms with a higher proportion of foreign investors had higher levels of investment efficiency because these investors were able to fulfill their role as monitors effectively, which had a positive impact on management's investing activities. Yim et al. (2014) suggest that firms belonging to large business groups enjoyed better investment efficiency levels than other firms unrelated to this type of business group and that firms with higher rates of independent directors were able to curb over-investing, allowing for improved levels of investment efficiency. Corroborating the findings of McNichols and Stubben (2008), Choi and Kwak (2010) also document that Korean firms subject to regulatory enforcement were positively associated with over-investment. In sum, the effective monitoring of managerial investment decisions and/or the provision of higher-quality financial reports to reduce information asymmetry between the firm and external constituents contribute to improvements in capital allocation and investment and hence investment efficiency.

\section{Hypothesis development}

Boards play an important role by monitoring and mitigating opportunistic behavior by management, specifically management's tendency to consume perquisites, and they help to reduce empire building (Charreaux and Desbrières 1998), which destroys firm value. Board members also have a direct influence on senior management's decision-making activities as they relate to various operating, investment and financial reporting activities. Greater board independence is considered effective when monitoring managerial behavior as well (Beasley 1996; Kim 2006; Kim and Bae 2007; Klein 2002; Xie et al. 2003).

Current research on gender at the corporate board level documents that gender characteristics affect corporate outcomes. Firms with at least one female director or firms with a higher proportion of female directors on their audit committees show more auditing effort and reduced levels of earnings management (Adams and Ferreira 2009; Gul et al. 2008). Post and Byron (2015) also find that female board representation brings a range of experience to boards, which positively fulfills the responsibilities of monitoring and the shaping of board strategies as boards deal with increasingly complex and uncertain business issues. This may arise because female directors generally base their decisions on detailed information compared to male directors when assessing issues raised by the board (Milliken and Martins 1996). The authors further contend that this relationship is more positive in countries with stronger shareholder protection and gender parity levels. In addition, prior research has suggested that female corporate directors are more attuned to environmental, social, and ethical issues (Simga-Mugan et al. 2005; Wahn 2003), implying that their presence reinforces the monitoring role of the board. 
Studies also show that female board representation is associated with better performance. Carter et al. (2003) document that boards with a higher fraction of female directors are associated with better firm performance. Similar results are found in Chinese-listed firms as well (Liu et al. 2014). Mukarram et al. (2018) find that women directors at publicly traded high-tech firms improve market performance but negative at other types of firms. Even multinational firms operating in Korea see better firm performance, as a ten percent nominal increase in the proportion of female managers is positively associated with a one percent increase in ROA. This is because multinational companies take advantage of the rich pool of qualified Korean women who are discriminated against at Korean firms (Siegel et al. 2011). Similarly, Siegel et al. (2014) show that the presence of female executives improves corporate profits at Japanese firms in the manufacturing sector. Chung et al. (2019) find that institutional blockholders monitor chaebol firms that improve their CSR index, which eventually enhances long-term performance. Perhaps, Korean women board members will do the same at the firms that employ them because individuals who benefit from diversity initiatives will promote them (Bader et al. 2018). Owen and Temesvary (2018) also find a positive effect of female board participation and various bank performance measures, conditioned on reaching a certain threshold of gender diversity. Other studies find that stock price informativeness and earnings quality improve when women are assigned to the board (Gul et al. 2011; Srinidhi et al. 2011). However, Sila et al. (2016) find no relationship between board diversity and firm risk, and some research documents negative aspects of such appointments on firm risk, stock prices, and firm performance (Ahern and Dittmar 2012; GregorySmith et al. 2014; Haslam et al. 2010; Matsa and Miller 2013).

In financial reporting, women tend to be more compliant in applying accounting rules and are less aggressive in their accounting choices. This results in lower rates of restatements than their male counterparts and allows companies with female CFOs to have higher accounting reporting quality levels as well (Abbott et al. 2012; Barua et al. 2010; Gull et al. 2018). This is consistent with studies using Korean data. Jung (2002) finds that female CPAs and analysts estimate contingent losses more conservatively, and Shawn and Jung (2013) find that firms audited by a female audit engagement partner are associated with lower discretionary accruals due to greater conservatism, which increases the odds of receiving a clean opinion. Even Kim et al. (2017) conclude that female executives in top management at Korean firms help curb opportunistic financial reporting. In relation to this, Kim and Hong (2015) find that the number of female directors is effective in reducing discretionary accruals at firms with strong corporate governance, findings that are in line with those of Jeon et al. (2017), who report that firms with diverse boards that include female director(s) show a strengthened monitoring function, which reduces real earnings management. Kim and Oh (2017) report that the proportion and tenure of female executives positively affect abnormal earnings and the relevance of net assets to the stock price. Moreover, the benefits of gender-diverse boards facilitate board discussions by departing from the viewpoint of the conventional 'old boys' club, enabling effective dialogue among members. This in turn reduces information asymmetry and increases the efficiency of the decision-making process, therefore improving transparency 
(Hillman et al. 2007; Rose 2007), which is critical to improving investment efficiency (Biddle and Hilary 2006; Biddle et al. 2009; McNichols and Stubben 2008; Verdi 2006). Based on the aforementioned discussion, female board members have the potential to increase the monitoring of various business ventures and are likely to exert influence across a wide spectrum of activities, including decisions with respect to investments. Hence, under the efficiency-enhancing view, we expect that women will enhance the monitoring role of boards on investment decisions, thereby deterring suboptimal over- or under-investments that deviate from the optimal investment levels. Hence, we state our first hypothesis based on the efficiency-enhancing view as follows:

Efficiency-enhancing hypothesis (H1) Firms with the presence of a female director will have a positive association with investment efficiency.

However, at the same time, certain women characteristics may also work against improving investment efficiency. While some studies find that gender diversity on top executive teams is associated with lower risk and better performance (Perryman et al. 2016), other research documents negative aspects of such appointments on firm risk, stock prices, and firm performance levels, as noted earlier (Ahern and Dittmar 2012; Haslam et al. 2010; Matsa and Miller 2013). However, other studies do not even find such a relationship (Sila et al. 2016). Hence, female characteristics may not always improve firm performance or promote investment efficiency.

According to behavioral finance tenets, in contrast to men, women generally exhibit greater risk-aversion and make more conservative investment choices (Charness and Gneezy 2012; Cohn et al. 1975; Croson and Gneezy 2009; Eckel and Grossman 2008). Levi et al. (2014) find that firms with female directors make fewer acquisitions and pay lower bid premia because women tend to be less confident in their estimations. One reason is that confidence is associated with risk attitudes, where Croson and Gneezy (2009) show that women are more risk-averse. Investigating transitions of CEOs, from male to female, Faccio et al. (2016) find that these firms experience a reduction in corporate risk-taking. Furthermore, they find that companies headed by female CEOs have less debt, lower earnings volatility, and a greater chance at survival than those led by male CEOs. Incentive packages are also designed differently between the genders, partly due to women having greater risk-aversion levels (Kulich et al. 2011).

If a female director's risk-aversion and conservatism have the potential significantly to affect a firm's efficient allocation of resources and investment decisions, we expect that a positive relationship between female board representation and investment efficiency will manifest given the deterrence of over-investment rather than a reduced level of under-investment, giving rise to the (excessive) risk-aversion view. Under the risk-aversion view, we expect that the presence of female board members will moderate the level of over-investment. Therefore, we state our second hypothesis based on the risk-aversion view, as follows: 
Table 1 Sample selection

\begin{tabular}{ll}
\hline Sample selection criteria & $\begin{array}{l}\text { Firm-year } \\
\text { observations }\end{array}$ \\
\hline $\begin{array}{l}\text { Initial firm-years of non-financial firms listed on } \\
\text { KOSPI over the period of 2006-2014 }\end{array}$ & 6413 \\
$\begin{array}{l}\text { (-) Observations with non-December fiscal year ends } \\
\text { and firms within the financial industries }\end{array}$ & 595 \\
(-) Observations with insufficient financial data & 2070 \\
(=) Final Sample & 3748 \\
\hline
\end{tabular}

Risk-aversion hypothesis (H2) The positive relationship between the presence of female corporate directors and investment efficiency will be more pronounced at firms that over-invest rather than at firms that under-invest.

\section{Sample and methodology}

\section{Sample selection}

Our sample period spans from 2006 to 2014 and begins by including all non-financial companies that are listed on the Korean Stock Exchange Index (KOSPI) as of December 31, 2014. We start from 2006 to control for the regulatory effects of the Equal Employment Opportunity and Work Family Balance Assistance Act, which went into effect during the same year. We obtain financial information required to conduct our analyses from KIS-Value and FnGuide, which are widely used comprehensive databases that contain firm-related information for all publicly traded companies listed on the Korean Stock Exchange (KSE). We acquire board composition information from TS2000, another widely used database that updates governancerelated variables of all publicly traded companies.

Because information on the gender of corporate directors is not readily available, we manually collected data directly from corporate filings (annual reports) listed on the Data Analysis, Retrieval and Transfer System (DART), which according to Korean law must be submitted to the Financial Supervisory Service (FSS), and augmented our data using profile information from the Korea Listed Companies Association and from the Korean Women Entrepreneurs Association to further obtain profile information about our women directors. Our data show that the majority of female executives with board seats were insiders who worked in the capacity of either a CEO or CFO within the firm and that the appointment of outside women directors was rare. Although most of the firms contained one female director, we find some variation in the total number of female directors, with a range of one to four within our sample. Further, these female directors were CEOs and CFOs promoted within the firm, and outside appointments of women directors were rare.

We restricted our sample to firms with fiscal years ending in December 31 to maintain homogeneity within our sample and further excluded firms with insufficient data. This leaves us with a final sample of 3748 firm-years with observations 
winsorized at the $1 \%$ and $99 \%$ level to minimize the influence of outliers. Table 1 summarizes our sample selection process.

\section{Models and variables}

\section{Female directors and investment efficiency}

To examine whether the presence of female directors is associated with investment efficiency, we start with the McNichols and Stubben (2008) model to estimate the predicted level of investment given the firm's investment opportunities. We then classify firms with female board presence if the board contains at least one female director (FEMALE). FEMALE is coded as 1 if a firm has at least one woman corporate director and 0 otherwise. We follow the McNichols and Stubben (2008) model to measure investment efficiency, as described in Eq. (1) below,

$$
\begin{aligned}
\operatorname{INVEST}_{i, t}= & a_{0}+a_{1} T q_{i, t-1}+\sum_{j=2}^{j=10} a_{j} T q_{i, t-1} \times \operatorname{Dec}_{j i, t-1}+a_{11} \text { CFO }_{i, t-1} \\
& +a_{12} \text { Grow }_{i, t-1}+a_{13} \text { INVEST }_{i, t-1}+\varepsilon_{i, t}
\end{aligned}
$$

where $I N V E S T_{i, t}$ is the increases in capital expenditures from the statement of cash flows/beginning of year total assets; $T q_{i, t-1}$ is the Tobin's Q (market value of equity + book value of debt)/book value of total assets; $D e c_{j i, t-1}$ is the industry-year distribution Tobin's Q, where Dec is the 1 if Dec falls into any deciles of the industryyear distribution across $2,3,4,5,6,7,8,9,10$; otherwise $0 ; C F O_{i, t-1}$ is the cash flow from operations/beginning of year total assets; Grow $w_{i, t-1}$ is the (total assets at year-end - total assets at beginning of year)/beginning of year total assets; $A B I N V$ is the estimated residuals $\left(\varepsilon_{i, t}\right)$ from Eq. (1).

McNichols and Stubben (2008) modified the model of Eq. (1) following Modigliani and Miller (1958), who state that investments depend on investment opportunities only and following Tobin (1969), who suggests that the marginal Tobin's Q (Tq) summarizes investment opportunities. We include cash flow from operations (CFO) to control for differences in a firm's internal financing capability, and Grow and the prior year's INVEST figures to mitigate measurement error that can arise when estimating Tobin's Q. Dec is a dummy variable that represents industry-year deciles and is coded as 1 if Dec falls into either the second, third, fourth, fifth, sixth, seventh, eighth, ninth, or tenth decile of its industry-year distribution. We also include an interaction term between $D e c$ and $T q$ to relax the strict assumption of linearity owing to possible variations between the two variables.

The estimated coefficients from Eq. (1) that explains INVEST represent the normal (optimal) level of investment, whereas the residuals represent firm-specific investments that deviate from normal levels. Stated differently, residuals with a positive (+) sign represent over-investment and residuals with a negative (-) sign represent under-investment. Therefore, we use values predicted by their model as a benchmark to determine the optimal level of investment. We acknowledge that the 
history of a firm's investments may not approximate the appropriate investment level for future growth and that the potential investment level may substantially deviate from predicted values depending on the changes in the current economic and operating environment. However, the authors developed their model based on optimal investment literature under the assumption that the estimated value of investment from their model captures a good portion of investment with nearly optimal values. Following the authors, excessive levels of investment are those that deviate from the predicted value, thus representing inefficiencies. ${ }^{2}$

\section{Model}

To test our first hypothesis of whether female board representation has a positive effect on investment efficiency, we use the following model described in Eq. (2):

$$
\begin{aligned}
A B S \_A B I N V_{i, t+1}= & \beta_{0}+\beta_{1} F E M A L E_{i, t}+\beta_{2} S I Z E_{i, t}+\beta_{3} M B_{i, t} \\
& +\beta_{4} L E V_{i, t}+\beta_{5} F r e e C F_{i, t}+\beta_{6} C F O \_S A L E_{i, t} \\
& +\beta_{7} R O A_{i, t}+\beta_{8} S D \_C F O_{i, t}+\beta_{9} S D \_S A L E_{i, t} \\
& +\beta_{10} S D \_I N V_{i, t}+\beta_{11} T A N G I B I L I T Y_{i, t}+\beta_{12} A G E_{i, t} \\
& +\beta_{13} B O D \_S I Z E_{i, t}+Y E A R, I N D+v_{i, t}
\end{aligned}
$$

In this model, the following are defined:

$A B S \_A B I N V$ is the the absolute value of residuals (ABINV) derived from Eq. (1), FEMALE is the dummy variable, 1 if the board has at least one female director, and 0 otherwise, SIZE is the the natural logarithm of common stock outstanding x market price (market capitalization), $M B$ is the the market-to-book ratio measured as market capitalization/book value of net assets, $L E V$ is the the ratio of the book value of liability to the book value of net assets, Free $C F$ is the free cash flow, measured as "(net income + depreciation expenses $-\Delta$ in tangible assets $-\Delta$ in net working capital)/beginning of the year total assets", CFO_SALE is the cash flow from operations (CFO)/sales, ROA is the net income/total assets, $S D \_C F O$ is the standard deviation of CFO/beginning of year total assets for the past five years, SD_SALE is the standard deviation of sales/beginning of year total assets for the past five years, $S D \_I N V$ is the standard deviation of investment in PPE/beginning of the year total tangible assets for the past five years, TANGIBILITY is the tangible assets/total assets, $A G E$ is the the firm's age from year listed on the Korean stock market to the

\footnotetext{
${ }^{2}$ Verdi (2006) and Biddle et al. (2009) conceptually define a firm that invests efficiently as one that takes on a positive-NPV project. For example, over-investment is when a firm accepts a negative-NPV project and under-investment is when a firm declines a positive-NPV project. Although McNichols and Stubben (2008) define inefficient investments that deviate from the predicted (estimated) value, this may not accurately capture the NPV of investment projects, which may be a limitation of their model. Hence, we retest our hypothesis with an alternative model suggested by Biddle et al. (2009) and find consistent results. See "Appendix 3" for the results (Table 12).
} 
current fiscal year, BOD_SIZE is the the natural logarithm of the total number of board members, YEAR, IND is the dummy variables for years and industries.

The dependent variable, $A B S \_A B I N V$, is derived from Eq. (1) which is the absolute value of the residuals. Greater values of $A B S \_A B I N V$ indicate greater deviations from the optimal level of investment. The variable of interest, FEMALE, is a dummy variable that takes on a value of one when at least one female director is present, and zero otherwise. As stated in our first hypothesis, if boards with female director representation effectively heighten their monitoring role and thus enabling a firm to make efficient investment decisions, then we expect the coefficient of FEMALE to be negative $\left(\beta_{1}<0\right)$. However, if $\beta_{1}$ is not significant or is positive then this may indicate that female directorship either does not affect investment efficiency meaningfully or that female directorship and investment efficiency may have a negative association.

We include a series of control variables that affect levels of investment, consistent with the investment literature. To control for firm characteristics related to investment, we include $S I Z E$ and $M B$. To control for external financing constraints given that firms differ in their investment opportunities, we include $L E V$, FreeCF, CFO_ $S A L E$, and ROA (Biddle et al. 2009; Doo et al. 2016). To control for volatility in cash flow and in sales that affect investment decisions, we include $S D \_C F O$ and $S D \_S A L E$. To rule out the possibility that over- and under-investment are affected by investment volatility itself, we control for $S D_{-} I N V$. To control for differences in investment opportunities, we include TANGIBILITY and AGE (Biddle and Hilary 2006; Biddle et al. 2009; Doo et al. 2016). Corporate boards play a critical role in making sound investment decisions. For boards to be effective, Vafeas (2000) asserts that the board size matters. Hence, we control for BOD_SIZE to assess the marginal effect of female directorship in association with investment efficiency. Lastly, we control for industry and year fixed effects.

To test our second hypothesis of whether women directors are able to improve investment efficiency at firms with more pronounced over-investment as compared to firms with under-investment, we bifurcate the sample into two groups based on the sign of $A B I N V$. Specifically, $A B I N V$ with a positive sign is classified as the overinvestment group and $A B I N V$ with a negative sign is classified as the under-investment group. As predicted in $\mathrm{H} 2$, if the presence of female directors can effectively mitigate incidences of over-investment rather than reduce levels of under-investment, consistent with the psychology and behavioral literature, then we expect the negative coefficient for the relationship between FEMALE and $A B S \_A B I N V$ to be stronger in the over-investment group than in the under-investment group.

\section{The Heckman (1979) two-stage regression to control for endogeneity}

As noted above, selection bias can be a concern within our sample when comparing the results for firms with female representation and without such representation. Estimates for the mean test and Wilcoxon median test presented in Table 4 can demonstrate the potential for selection bias. To avoid this, in this section we employ Heckman (1979) two-stage regression to control for endogeneity to alleviate 
selection bias concerns and retest hypotheses 1 and 2 to buttress our results as a robustness check. Specifically, we attempt to attenuate the potential concern that the positive relationship between female directors and efficiency is due to firm-specific characteristics. Accordingly, in the first stage we use a probit model with FEMALE as the dependent variable and firm-specific characteristics as the independent variable in order to obtain the inverse Mills ratio $(I M R)$, following previous studies that consider specific firm characteristics to be associated with the hiring of female directors (Shawn and Jung 2013; Srinidhi et al. 2011). In the second stage, we include the $I M R$ derived from the first stage to retest our predictions.

$$
\begin{aligned}
\text { FEMALE }_{i, t}= & \beta_{0}+\beta_{1} \text { ROA }_{i, t}+\beta_{2} \text { SIZE }_{i, t}+\beta_{3} M B_{i, t}+\beta_{4} L E V_{i, t}+\beta_{5} L_{\text {OSS }}, \\
& +\beta_{6} \text { AUDITOR }_{i, t}+\beta_{7} \text { BOD_SIZE } \\
i, t & +\lambda_{i, t}
\end{aligned}
$$

where the dummy variable LOSS equals 1 when net income $<0$, and 0 otherwise. AUDITOR is also a dummy variable that equals 1 when a firm hires a Big 4 auditor, equaling 0 otherwise. Other variables are defined as shown in Table 2.

\section{Empirical results}

\section{Descriptive statistics and correlation}

In Table 2, Panels A and B present the sample distribution by industry and year, respectively. Panel A shows that firms within the agriculture, forestry, and fishing industry have the highest proportion of female corporate directors $(28.89 \%)$ with services $(9.05 \%)$, manufacturing $(7.61 \%)$, and wholesale and retail trade following. However, firms in the construction industry have a conspicuously lower rate of female corporate directors $(0.53 \%)$, which implies that women directors in the construction industry are significantly underrepresented and that women still lag behind in their career opportunities within this sector.

Table 2, Panel B presents the distribution of the number and percentages of female directors by year. Our sample shows that the percentage of female directors increases somewhat earlier in the sample period and then remains at about seven percent in the later period. However, the number of female directors increases overall, with a slight drop in 2010. This moderate upward trend of women board representation reflects the progress that women have made at Korean firms and indicates that the purpose and implication of this study which attempts to recognize their role as board members is timely.

Table 2, Panel $\mathrm{C}$ reports descriptive statistics of the main variables used in this study. The absolute value of $A B I N V\left(A B S \_A B I N V\right)$, which is the dependent variable, has a mean (median) of $0.0748(0.0215)$ with a standard deviation of 0.1739 . The mean (median) of $A B I N V$ is $-0.0022(-0.0000)$ and its standard deviation is 0.1402 . This implies that on average, firms in our sample tend to under-invest. The variable of interest, FEMALE, has a mean (median) of 0.0755 (0.0000), meaning that $7.55 \%$ (283/3748 firm-years) of the total sample contains a female corporate director. 
Table 2 Sample distribution

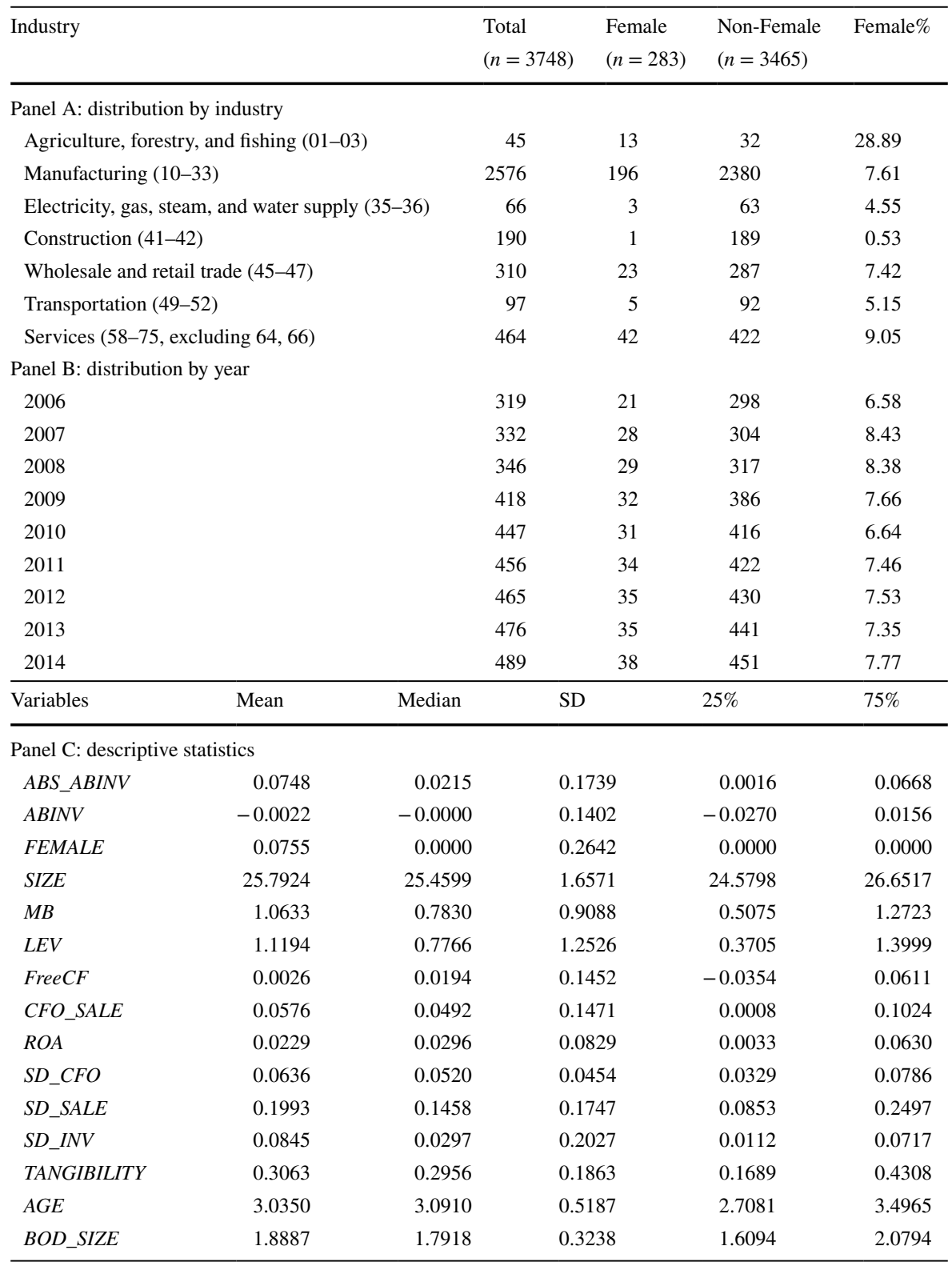

Panel A and B report the sample distribution by industry and year, respectively; panel C reports descriptive statistics for variables used in the analyses; Definition of variables used in the analyses is summarized as follows: $A B I N V$ is the level of abnormal investment which is the residuals from Eq. (1); $A B S_{-}$ $A B I N V$ is the absolute value of $A B I N V$; FEMALE is the dummy variable set to 1 if a firm has at least one female director on the board, 0 otherwise; $S I Z E$ is the natural log of market capitalization; $M B$ is the market-to-book ratio calculated as the market capitalization/the book value of net assets; $L E V$ is the ratio of book value of liability to book value of net assets; FreeCF is the free cash flows calculated as "(net income + depreciation expenses - changes in tangible assets - changes in net working capital)/lagged 
Table 2 (continued)

total assets"; $C F O \_S A L E$ is the cash flows from operations/sales; $R O A$ is the net income/total assets; $S D \_C F O$ is the standard deviation of cash flows from operations/lagged total assets for the past 5 years; $S D \_S A L E$ is the standard deviation of sales/lagged total assets for the past 5 years; $S D \_I N V$ is the standard deviation of investment in PPE/lagged total tangible assets for the past 5 years; TANGIBILITY is the total tangible assets/total assets $A G E$ is the firm's age from the year a firm is listed on the Korean stock market to the current fiscal year; BOD_SIZE is the natural log of the total number of board members

Table 3 presents the Pearson (Spearman) correlation of the variables used in the regression. The variable of interest, FEMALE and $A B S \_A B I N V$, has a negative correlation but is not significant. Looking at the relationship between FEMALE and the other control variables, SIZE, $M B, R O A$, and BOD_SIZE have a significantly positive relationship (Spearman correlations), which implies that larger firms, firms with greater growth opportunities, firms with better performance, and firms with larger boards tend to hire female directors as board members. On the other hand, female board participation and volatility in cash flows and sales ( $S D \_C F O$ and $S D \_S A L E$ ) are significantly negative. These statistics indicate that the association between female directorship and investment efficiency may be determined by firm characteristics that introduce selection bias into our sample. Hence, we control for this sample selection bias problem by adopting Heckman (1979) two-stage regression and present the results in the multivariate analysis section.

\section{Multivariate analysis}

In Table 4, Panel A presents the univariate tests between the group of firms with female directors (Female) on the board and the group without (Non-Female). We use the $T$ test and the Wilcoxon test to show the differences in the mean and median between both groups, respectively. Looking at $A B S \_A B I N V$, the statistical difference in the mean between the two groups is marginal but, on average, the Non-Female group tends to show more inefficient investment behavior than the Female group (Non-Female group $=0.0758$, Female group $=0.0620$; the difference test shows a $p$ value of 0.099). Looking at the control variables, the Female group shows a larger firm size and a greater $M B$ ratio than the Non-Female group. In addition, board size in the Female group indicates, on average, 1.14 more directors on the board. ${ }^{3}$ In contrast, the Non-Female group exhibits a higher $L E V$, a higher standard deviation of cash flows from operations $\left(S D \_C F O\right)$, and a greater standard deviation of changes in sales $\left(S D \_S A L E\right)$. These statistics corroborate the results found in Table 3, which illustrates the existence of different firm characteristics between the two groups and that significantly more abnormal levels of investments are made in the Non-Female group than in the Female group. Hence, this univariate analysis provides initial support for our first hypothesis.

\footnotetext{
3 BOD_SIZE is measured as the natural log of the total number of board members and is calculated as $\mathrm{e}^{(2.0083-\overline{1} .8789)}$.
} 


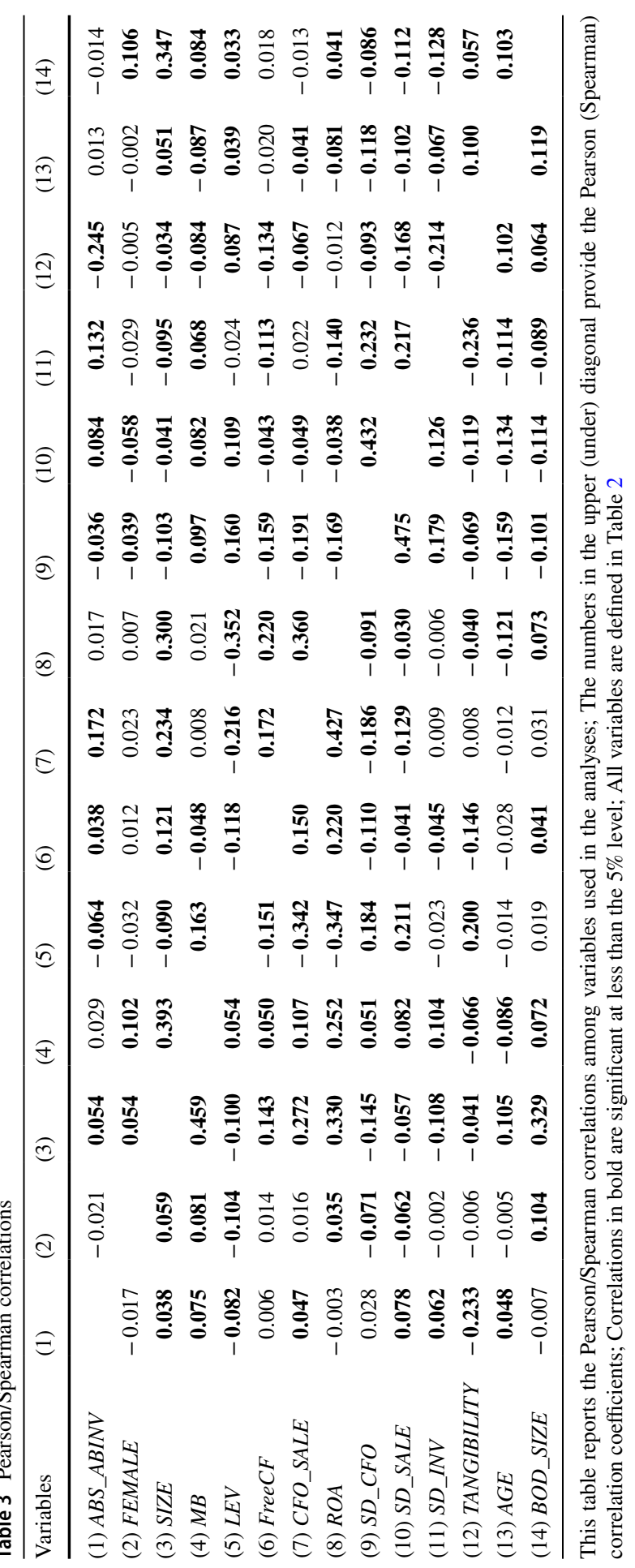


Table 4 Univariate tests

Panel A: $T$ test and Wilcoxon test for the full sample

\begin{tabular}{|c|c|c|c|c|c|c|}
\hline \multirow[t]{2}{*}{ Variables } & \multicolumn{2}{|c|}{ Female $(n=283)$} & \multicolumn{2}{|c|}{ Non-Female $(n=3465)$} & \multicolumn{2}{|c|}{$\begin{array}{l}\text { Difference tests: ( } p \\
\text { value) }\end{array}$} \\
\hline & Mean & Median & Mean & Median & Mean & Median \\
\hline$A B S \_A B I N V$ & 0.0620 & 0.0176 & 0.0758 & 0.0218 & 0.099 & 0.179 \\
\hline SIZE & 26.1047 & 25.8569 & 25.7669 & 25.4249 & $<0.001$ & $<0.001$ \\
\hline$M B$ & 1.3886 & 0.9500 & 1.0367 & 0.7702 & $<0.001$ & $<0.001$ \\
\hline$L E V$ & 0.9797 & 0.5007 & 1.1308 & 0.7972 & 0.025 & $<0.001$ \\
\hline FreeCF & 0.0086 & 0.0230 & 0.0022 & 0.0188 & 0.246 & 0.202 \\
\hline$C F O \_S A L E$ & 0.0693 & 0.0597 & 0.0566 & 0.0490 & 0.081 & 0.164 \\
\hline$R O A$ & 0.0249 & 0.0366 & 0.0227 & 0.0291 & 0.335 & 0.017 \\
\hline$S D \_C F O$ & 0.0575 & 0.0412 & 0.0641 & 0.0528 & 0.008 & $<0.001$ \\
\hline$S D \_S A L E$ & 0.1635 & 0.1124 & 0.2022 & 0.1480 & $<0.001$ & $<0.001$ \\
\hline$S D \_I N V$ & 0.0637 & 0.0346 & 0.0862 & 0.0295 & 0.003 & 0.457 \\
\hline TANGIBILITY & 0.3031 & 0.2843 & 0.3066 & 0.2968 & 0.379 & 0.367 \\
\hline$A G E$ & 3.0307 & 3.1355 & 3.0354 & 3.0910 & 0.442 & 0.378 \\
\hline BOD_SIZE & 2.0083 & 1.9459 & 1.8789 & 1.7918 & $<0.001$ & $<0.001$ \\
\hline
\end{tabular}

Panel B: $T$ test and Wilcoxon test for subsamples classified as over-investment and under-investment

\begin{tabular}{|c|c|c|c|c|c|c|}
\hline \multirow[t]{2}{*}{$\mathrm{ABINV}>0$} & \multicolumn{2}{|c|}{ Female $(n=134)$} & \multicolumn{2}{|c|}{ Non-Female $(n=1626)$} & \multicolumn{2}{|c|}{$\begin{array}{l}\text { Difference tests: ( } p \\
\text { value) }\end{array}$} \\
\hline & Mean & Median & Mean & Median & Mean & Median \\
\hline$A B S \_A B I N V$ & 0.0442 & 0.0129 & 0.0778 & 0.0197 & 0.013 & 0.077 \\
\hline $\mathrm{ABINV}<0$ & \multicolumn{2}{|c|}{ Female $(n=149)$} & \multicolumn{2}{|c|}{ Non-Female $(n=1839)$} & \multicolumn{2}{|c|}{$\begin{array}{l}\text { Difference tests: ( } p \\
\text { value) }\end{array}$} \\
\hline Variables & Mean & Median & Mean & Median & Mean & Median \\
\hline$A B S \_A B I N V$ & 0.0781 & 0.0225 & 0.0732 & 0.0239 & 0.369 & 0.432 \\
\hline
\end{tabular}

Panel A describes the results of the $T$ test and Wilcoxon test for variables used in the analyses between the Female and Non-Female groups; panel B shows the results of the $T$-test and Wilcoxon test for groups classified as over-investment (ABINV $>0)$ and under-investment $(\mathrm{ABINV}<0)$ and then between groups of Female and Non-Female, respectively ( $p$ values for the $t$ statistic and $Z$ statistic are one tailed)

In Table 4, Panel B presents the $T$ test and Wilcoxon test results for samples initially classified into over- and under-investment groups $(A B I N V>0$ and $A B I N V<0)$ and then classified into Female and Non-Female groups. In terms of over-investment $(A B V I N V>0)$, the Non-Female group shows, on average, a difference of $0.0336(0.0778-0.0442)$ with regard to higher levels of over-investment than the Female group. This finding is statistically significant at the 5\% level. However, in terms of under-investment $(A B V I N V<0)$, we do not find a statistically significant difference between the two groups. In sum, the aforementioned univariate tests provide initial support for our second hypothesis. That 
Table 5 Cross-sectional regressions: full sample and subsamples

\begin{tabular}{|c|c|c|c|}
\hline \multicolumn{4}{|c|}{ Dependent variable: $A B S \_A B I N V$} \\
\hline Variables & $\begin{array}{l}\text { (1) } \\
\text { Full sample }\end{array}$ & $\begin{array}{l}\text { (2) } \\
\text { Over-investment }\end{array}$ & $\begin{array}{l}\text { (3) } \\
\text { Under-investment }\end{array}$ \\
\hline Intercept & $\begin{array}{l}0.0171 \\
(0.39)\end{array}$ & $\begin{array}{l}0.0600 \\
(0.88)\end{array}$ & $\begin{array}{l}-0.0292 \\
(-0.48)\end{array}$ \\
\hline FEMALE & $\begin{array}{l}-0.0202 * * \\
(-2.40)\end{array}$ & $\begin{array}{l}-0.0323 * * * \\
(-2.73)\end{array}$ & $\begin{array}{l}-0.0071 \\
(-0.57)\end{array}$ \\
\hline SIZE & $\begin{array}{l}-0.0004 \\
(-0.23)\end{array}$ & $\begin{array}{l}-0.0022 \\
(-0.86)\end{array}$ & $\begin{array}{l}0.0017 \\
(0.66)\end{array}$ \\
\hline$M B$ & $\begin{array}{l}-0.0033 \\
(-1.16)\end{array}$ & $\begin{array}{l}0.0027 \\
(0.55)\end{array}$ & $\begin{array}{l}-0.0083^{* *} \\
(-2.00)\end{array}$ \\
\hline$L E V$ & $\begin{array}{l}0.0029 \\
(1.25)\end{array}$ & $\begin{array}{l}-0.0006 \\
(-0.17)\end{array}$ & $\begin{array}{l}0.0053^{*} \\
(1.69)\end{array}$ \\
\hline FreeCF & $\begin{array}{l}-0.0118 \\
(-0.52)\end{array}$ & $\begin{array}{l}-0.0341 \\
(-1.15)\end{array}$ & $\begin{array}{l}0.0022 \\
(0.07)\end{array}$ \\
\hline$C F O \_S A L E$ & $\begin{array}{l}0.0647^{*} \\
(1.75)\end{array}$ & $\begin{array}{l}0.0713 \\
(1.17)\end{array}$ & $\begin{array}{l}0.0556 \\
(1.25)\end{array}$ \\
\hline$R O A$ & $\begin{array}{l}0.0228 \\
(0.58)\end{array}$ & $\begin{array}{l}-0.0257 \\
(-0.52)\end{array}$ & $\begin{array}{l}0.0708 \\
(1.17)\end{array}$ \\
\hline$S D \_C F O$ & $\begin{array}{l}-0.0744 \\
(-0.92)\end{array}$ & $\begin{array}{l}-0.1956 \\
(-1.52)\end{array}$ & $\begin{array}{l}0.0523 \\
(0.61)\end{array}$ \\
\hline$S D \_S A L E$ & $\begin{array}{l}0.0194 \\
(0.94)\end{array}$ & $\begin{array}{l}0.0357 \\
(1.00)\end{array}$ & $\begin{array}{l}0.0054 \\
(0.20)\end{array}$ \\
\hline$S D \_I N V$ & $\begin{array}{l}0.0507 * * \\
(2.42)\end{array}$ & $\begin{array}{l}0.0965 * * * \\
(3.79)\end{array}$ & $\begin{array}{l}0.0016 \\
(0.09)\end{array}$ \\
\hline TANGIBILITY & $\begin{array}{l}-0.0559 * * * \\
(-3.89)\end{array}$ & $\begin{array}{l}-0.0541^{* *} \\
(-2.21)\end{array}$ & $\begin{array}{l}-0.0551 * * * \\
(-3.09)\end{array}$ \\
\hline$A G E$ & $\begin{array}{l}-0.0047 \\
(-0.85)\end{array}$ & $\begin{array}{l}-0.0162 * * \\
(-2.01)\end{array}$ & $\begin{array}{l}0.0078 \\
(1.00)\end{array}$ \\
\hline BOD_SIZE & $\begin{array}{l}0.0070 \\
(0.91)\end{array}$ & $\begin{array}{l}0.0033 \\
(0.27)\end{array}$ & $\begin{array}{l}0.0081 \\
(0.74)\end{array}$ \\
\hline Year fixed effect & Included & Included & Included \\
\hline Industry fixed effect & Included & Included & Included \\
\hline Adj_R $R^{2}$ & 0.2640 & 0.3001 & 0.2373 \\
\hline Observations & 3748 & 1760 & 1988 \\
\hline
\end{tabular}

This table reports the results of hypothesis 1 and $2 ; * * *$, and *** denote significance at the 10,5 , and $1 \%$ levels (two-tailed), respectively; standard errors are adjusted for firm-clustering (one-way clustering); all variables are defined in Table 2

is, the positive relationship observed between female directors on the board and investment efficiency indicates that the presence of female directors effectively reduces over-investment rather than reducing under-investment due to their riskaverse, conservative, and prudent nature. 


\section{The presence of female directors and investment efficiency}

Table 5 shows the cross-sectional regression results for our first hypothesis regarding whether firms with female directors are positively associated with investment efficiency. The dependent variable, $A B S \_A B I N V$, represents the absolute value of investment that diverges from optimal levels, where lower values of $A B S \_A B I N V$ imply greater investment efficiency. FEMALE, the variable of interest, is an indicator variable that takes on a value of 1 if a female director sits on the board and 0 otherwise. In order to support our first hypothesis, we expect a significantly negative coefficient for FEMALE, where greater (lower) values in $A B S \_A B I N V$ imply lower (higher) investment efficiency. The regression results show that the coefficient $\left(\beta_{1}\right)$ of FEMALE is -0.0202 , which is statistically significant at the $5 \%$ level, as shown in column (1) in the full sample, suggesting that boards with the presence of females are associated with better investment efficiency. Having established this relationship, we explore the direction of improvement and test our second hypothesis concerning whether female directors improve investment efficiency at firms that are more prone to over-invest. Hence, we further classify the full sample into subgroups of firms that have overinvested and under-invested to investigate the direction of the improvement. Our empirical results show that female directors appear to be instrumental in improving investment efficiency for firms that have over-invested, as shown in column (2), where the coefficient of FEMALE is significantly negative $\left(\beta_{1}=-0.0323, t=-2.73\right)$ at the $1 \%$ level while it is insignificant for firms that have under-invested, as shown in column (3). These results imply that female directors' contribution to improving investment efficiency is more pronounced at firms that are likely to over-invest than at firms that under-invest, which is consistent with the risk-aversion hypothesis.

A substantial body of work in behavioral studies reports that female directors are more independent and risk-averse than their male counterparts and that they improve the monitoring role of the board as well (Gul et al. 2011; Kang et al. 2007; Srinidhi et al. 2011). In addition, literature in this field documents that women directors reinforce board independence and in turn improve firm performance (Carter et al. 2003). Our results are also in line with previous studies that report a positive effect of female board representation on firm outcomes. ${ }^{4}$ Although our results are largely consistent with the risk-averse view, we provide some evidence that female directors are associated with better future performance at firms inclined to over-invest (see "Appendix 1", Table 10). We also replace the FEMALE variable with the number of female directors $(F N)$ and the ratio of the number of female directors to the total number of board members $(F N R)$ in our regression models. Our untabulated results show qualitatively consistent results which corroborate our previous findings that female board directors play a positive role in investment efficiency.

Another concern may be that our results are driven by the fact that ex-officio directors, such as female CEOs/CFOs, have significant effects on the outcomes of

\footnotetext{
${ }^{4}$ Our results show that investment efficiency partially occurs in over-investment and not in under-investment. For a further assessment of whether female board participation produces better outcomes, we conduct an additional analysis and find that firms with female board directors were able to improve future performance more than those without such representation. See "Appendix 1" for the results (Table 10).
} 
important investment decisions which are under the scrutiny of other board members. Hence, their clout could mask the effect of other female board directors. To rule out this possibility, we exclude female CEOs as another robustness check. In our untabulated analysis, we find qualitatively similar results. However, when excluding those firms with female CFOs, we could not obtain results due to a significant decrease in the sample size, which lowers the power of our tests.

Reviewing the control variables, the analysis shows that investment efficiency declines with increasing levels of investment variability $\left(S D \_I N V\right)$ and increases when TANGIBILITY is higher. Investment efficiency also shows a negative relationship with the ratio of $\mathrm{CFO}$ to sales $\left(C F O \_S A L E\right)$, suggesting that firms with sufficient amounts of cash holdings may over-invest, thereby deviating from efficient investment levels. Although other control variables do not show a statistically significant relationship with regard to efficient investing, our results are similar to those in prior studies (Biddle et al. 2009; Doo et al. 2016). We replicate our results by replacing $S I Z E$ with sales revenue and the number of employees. In addition, we replace $A G E$ with a firm's founding date instead of using the date the firm went public. Our (untabulated) results remain unchanged. In addition to controlling for industry and year fixed effects, we use one-way clustering (firmclustering) to correct for potential bias from under-estimated standard errors.

Table 6 reports the results on the effect of female board representation on investment efficiency, controlling for endogeneity using the Heckman (1979) twostage analysis. As stated earlier, the results in Table 5 may contain sample selection bias depending on the firm characteristics. Therefore, we address this concern by re-examining the relationship between female directors and investment efficiency. Consistent with our predictions, even with the inclusion of $I M R$, the two-stage analysis shows a significantly positive association between FEMALE and $A B S \_A B I N V\left(\beta_{1}=-0.0216, t=-2.53\right)$ at the $5 \%$ level in column (1) for the full sample. Reviewing the two subgroups that veer from optimal levels, the subsample of the over-investment group $(\mathrm{ABINV}>0)$ shows a significantly negative relationship $\left(\beta_{1}=-0.0344, t=-2.80\right)$ between the existence of female directors and investment efficiency at the $1 \%$ level in column (2), whereas this relationship is not significant $\left(\beta_{1}=-0.0069, t=-0.45\right)$ in the subsample group of underinvestment $(\mathrm{ABVINV}<0)$ shown in column $(3)$. Even the magnitude of the coefficient $(-0.0344)$ in the over-investment subsample group is approximately 5.73 times greater than that $(-0.0060)$ in the under-investment subsample group. These results lend support to our second hypothesis. Although we cannot completely rule out the issue of endogeneity and selection bias associated with incorporating firm-specific characteristics, these results provide more confidence with regard to our previous findings that female board directors have a positive and significant impact on investment efficiency, and more importantly that improvement in investment efficiency is found more at firms with over-investment than at those with under-investment.

As indicated in the behavioral finance literature, women generally tend to be more risk-averse and conservative in their investment decisions. As such, we expect these traits to manifest accordingly at firms with female corporate directors on investment decisions made by the board. The consistently positive 
Table 6 Heckman 2-stage analysis

\begin{tabular}{|c|c|c|c|}
\hline \multicolumn{4}{|c|}{ Dependent variable: $A B S \_A B I N V$} \\
\hline Variables & $\begin{array}{l}\text { (1) } \\
\text { Full sample }\end{array}$ & $\begin{array}{l}\text { (2) } \\
\text { Over-investment }\end{array}$ & $\begin{array}{l}\text { (3) } \\
\text { Under-investment }\end{array}$ \\
\hline Intercept & $\begin{array}{l}0.0995 \\
(1.50)\end{array}$ & $\begin{array}{l}0.2813 * * \\
(1.99)\end{array}$ & $\begin{array}{l}-0.0118 \\
(-0.15)\end{array}$ \\
\hline FEMALE & $\begin{array}{l}-0.0216^{* *} \\
(-2.53)\end{array}$ & $\begin{array}{l}-0.0334 * * * \\
(-2.80)\end{array}$ & $\begin{array}{l}-0.0069 \\
(-0.45)\end{array}$ \\
\hline$S I Z E$ & $\begin{array}{l}0.0006 \\
(0.32)\end{array}$ & $\begin{array}{l}-0.0012 \\
(-0.44)\end{array}$ & $\begin{array}{l}0.0023 \\
(0.71)\end{array}$ \\
\hline$M B$ & $\begin{array}{l}-0.0093^{*} \\
(-1.95)\end{array}$ & $\begin{array}{l}-0.0093 \\
(-1.07)\end{array}$ & $\begin{array}{l}-0.0116^{* *} \\
(-2.01)\end{array}$ \\
\hline$L E V$ & $\begin{array}{l}0.0065^{* *} \\
(2.12)\end{array}$ & $\begin{array}{l}0.0074 \\
(1.33)\end{array}$ & $\begin{array}{l}0.0062 * \\
(1.68)\end{array}$ \\
\hline Free $C F$ & $\begin{array}{l}-0.0129 \\
(-0.58)\end{array}$ & $\begin{array}{l}-0.0353 \\
(-1.19)\end{array}$ & $\begin{array}{l}0.0181 \\
(0.48)\end{array}$ \\
\hline$C F O \_S A L E$ & $\begin{array}{l}0.0598 \\
(1.61)\end{array}$ & $\begin{array}{l}0.0634 \\
(1.05)\end{array}$ & $\begin{array}{l}0.0638 \\
(1.29)\end{array}$ \\
\hline$R O A$ & $\begin{array}{l}0.0376 \\
(0.93)\end{array}$ & $\begin{array}{l}-0.0555 \\
(-1.06)\end{array}$ & $\begin{array}{l}0.0810 \\
(1.15)\end{array}$ \\
\hline$S D \_C F O$ & $\begin{array}{l}-0.0709 \\
(-0.89)\end{array}$ & $\begin{array}{l}-0.1901 \\
(-1.48)\end{array}$ & $\begin{array}{l}0.0645 \\
(0.68)\end{array}$ \\
\hline$S D \_S A L E$ & $\begin{array}{l}0.0234 \\
(1.11)\end{array}$ & $\begin{array}{l}0.0428 \\
(1.18)\end{array}$ & $\begin{array}{l}0.0072 \\
(0.26)\end{array}$ \\
\hline$S D \_I N V$ & $\begin{array}{l}0.0498 * * \\
(2.40)\end{array}$ & $\begin{array}{l}0.0946 * * * \\
(3.76)\end{array}$ & $\begin{array}{l}-0.0004 \\
(-0.02)\end{array}$ \\
\hline TANGIBILITY & $\begin{array}{l}-0.0501 * * * \\
(-3.47)\end{array}$ & $\begin{array}{l}-0.0449 * \\
(-1.81)\end{array}$ & $\begin{array}{l}-0.0592^{* * * *} \\
(-3.17)\end{array}$ \\
\hline$A G E$ & $\begin{array}{l}-0.0050 \\
(-0.89)\end{array}$ & $\begin{array}{l}-0.0168 * * \\
(-2.08)\end{array}$ & $\begin{array}{l}0.0093 \\
(1.00)\end{array}$ \\
\hline BOD_SIZE & $\begin{array}{l}-0.0131 \\
(-0.95)\end{array}$ & $\begin{array}{l}-0.0441 \\
(-1.53)\end{array}$ & $\begin{array}{l}0.0010 \\
(0.06)\end{array}$ \\
\hline$I M R$ & $\begin{array}{l}-0.0367 * \\
(-1.81)\end{array}$ & $\begin{array}{l}-0.0789 * * \\
(-2.33)\end{array}$ & $\begin{array}{l}-0.0132 \\
(-0.59)\end{array}$ \\
\hline Year fixed effect & Included & Included & Included \\
\hline Industry fixed effect & Included & Included & Included \\
\hline Adj_$R^{2}$ & 0.2644 & 0.3017 & 0.2230 \\
\hline Observations & 3748 & 1760 & 1988 \\
\hline
\end{tabular}

This table reports the results of hypotheses 1 and 2 after incorporating the Inverse Mills Ratio (IMR) from the Heckman (1979) two-stage analysis; *, **, and *** denote significance at the 10, 5, and 1\% levels (two-tailed), respectively; standard errors are adjusted for firm-clustering (one-way clustering); all variables are defined in Table 2

association between female board directors and investment efficiency demonstrated in Tables 5 and 6 stems from the consideration that the voices of women directors will help reduce over-investment, rather than under-investment. Hence, our analysis provides evidence that the aforementioned characteristics of female 
directors positively affect board discussions which improve efficiency and therefore appear to reduce wasteful over-investing, lending further support to our second hypothesis. ${ }^{5}$

Lastly, we also control for another endogeneity issue, i.e., the direction of causality. One may argue that the positive relationship between investment efficiency and the presence of female directors is attributed to the possibility that firms with higher investment efficiency are more likely to appoint a female director. To alleviate this reverse causality concern, we re-examine our results by employing a two-step system dynamic GMM (generalized method of moment) approach with Windmeijer-corrected standard errors. To apply the GMM approach, we include a lagged dependent variable as an instrumental variable ( $\left.L a g \_A B S \_A B I N V\right)$ in the regression model.

Table 7 reports the results of the GMM estimations. Again, the coefficient of FEMALE is negative and significant $\left(\beta_{1}=-0.0904, t=-1.77\right)$ at the $10 \%$ level, buttressing our findings that female board participation has a positive association with investment efficiency. In addition, the Hansen J-statistic from the over-identification test is statistically insignificant, suggesting that the instrument is valid in the two-step system GMM estimation. Furthermore, the result shows that the first-order autocorrelation [AR(1)] is significant while the second-order autocorrelation in the second differences $[\mathrm{AR}(2)]$ is insignificant, consistent with previous studies. Overall, these results indicate that the model is well specified to conduct GMM estimations and that both $\mathrm{H} 1$ and $\mathrm{H} 2$ are supported. In sum, a battery of robustness checks supports our findings.

\section{The moderating effects of female board directors}

Thus far, our main analyses for the second hypothesis are based on subsamples which are classified into over- and under-investment groups. However, to maintain consistency of our hypothesis, we alternatively examine the moderating role of women directors in reducing the level of over-investment. Therefore, we retest our hypothesis using a moderating model to further analyze whether a change in efficiency occurs at firms that appoint at least one or more female director(s) as an additional test.

Table 8 reports the results of the moderation model with female director representation. OVERINV is a dummy variable that equals 1 if the residual from Eq. (1) is above zero; otherwise it equals 0 . Therefore, to support our hypothesis, the coefficient $\left(\beta_{3}\right)$ of our variable of interest, FEMALE $\times O V E R I N V$, should be significantly negative in this moderating model. Reviewing the results, we find that the coefficient of FEMALE $\left(\beta_{1}\right)$ is negative but insignificant $\left(\beta_{1}=-0.0082, t=-0.68\right)$ and that the coefficient of $\operatorname{OVERINV}\left(\beta_{2}\right)$ is positive and significant $\left(\beta_{2}=0.0127, t=2.26\right)$

\footnotetext{
5 We follow the definition of over-investment predicated on previous research. That is, literature states that firms with greater levels of cash and cash equivalents and with lower levels of debt have the proclivity to over-invest (Jensen 1986; Harford 1999; Nini et al. 2009; Biddle et al. 2009; Yim et al. 2014).
} 
Table 7 GMM estimation

\begin{tabular}{|c|c|c|c|}
\hline \multicolumn{4}{|l|}{ Dependent variable: $A B S \_A B I N V$} \\
\hline Variables & $\begin{array}{l}\text { (1) } \\
\text { Full sample }\end{array}$ & $\begin{array}{l}\text { (2) } \\
\text { Over-investment }\end{array}$ & $\begin{array}{l}\text { (3) } \\
\text { Under-investment }\end{array}$ \\
\hline Lag_ABS_ABINV & $\begin{array}{l}-0.1284 * * * \\
(-2.81)\end{array}$ & $\begin{array}{l}-0.2131 * * * \\
(-3.78)\end{array}$ & $\begin{array}{l}-0.0362 \\
(-0.45)\end{array}$ \\
\hline FEMALE & $\begin{array}{l}-0.0904^{*} \\
(-1.77)\end{array}$ & $\begin{array}{l}-0.0935^{*} \\
(-1.72)\end{array}$ & $\begin{array}{l}-0.089 \\
(-0.54)\end{array}$ \\
\hline SIZE & $\begin{array}{l}-0.4714 * * \\
(-2.03)\end{array}$ & $\begin{array}{l}-0.0091 \\
(-0.86)\end{array}$ & $\begin{array}{l}0.0321 \\
(0.10)\end{array}$ \\
\hline$M B$ & $\begin{array}{l}0.1729 * \\
(1.96)\end{array}$ & $\begin{array}{l}0.0192 \\
(-0.94)\end{array}$ & $\begin{array}{l}-0.0535 \\
(-0.14)\end{array}$ \\
\hline$L E V$ & $\begin{array}{l}-0.0112 \\
(-0.70)\end{array}$ & $\begin{array}{l}0.0118 \\
(-4.95)\end{array}$ & $\begin{array}{l}0.0072 \\
(0.14)\end{array}$ \\
\hline Free $C F$ & $\begin{array}{l}0.0036 \\
(0.03)\end{array}$ & $\begin{array}{l}-0.6081 * * * \\
(-2.57)\end{array}$ & $\begin{array}{l}-0.4310 \\
(-1.27)\end{array}$ \\
\hline$C F O \_S A L E$ & $\begin{array}{l}0.0207 \\
(0.57)\end{array}$ & $\begin{array}{l}0.0140 * * \\
(-2.57)\end{array}$ & $\begin{array}{l}0.0293 \\
(0.71)\end{array}$ \\
\hline$R O A$ & $\begin{array}{l}0.5464^{* *} \\
(2.14)\end{array}$ & $\begin{array}{l}-0.0452 \\
(-0.50)\end{array}$ & $\begin{array}{l}0.8054^{*} \\
(1.82)\end{array}$ \\
\hline$S D \_C F O$ & $\begin{array}{l}1.6519 \\
(0.75)\end{array}$ & $\begin{array}{l}-3.3025 * * * \\
(-3.17)\end{array}$ & $\begin{array}{l}-6.1232 \\
(-1.49)\end{array}$ \\
\hline$S D \_S A L E$ & $\begin{array}{l}0.0150 \\
(0.07)\end{array}$ & $-0.0166^{*}(-0.19)$ & $\begin{array}{l}-0.1664 \\
(-0.23)\end{array}$ \\
\hline$S D \_I N V$ & $\begin{array}{l}-0.6036^{*} \\
(-1.69)\end{array}$ & $\begin{array}{l}0.0667 \\
(-1.39)\end{array}$ & $\begin{array}{l}0.6699 \\
(1.36)\end{array}$ \\
\hline TANGIBILITY & $\begin{array}{l}1.1280^{*} \\
(1.73)\end{array}$ & $\begin{array}{l}-0.7219 * * \\
(-2.32)\end{array}$ & $\begin{array}{l}0.4265 \\
(0.23)\end{array}$ \\
\hline$A G E$ & $\begin{array}{l}-3.0233 * * \\
(-2.32)\end{array}$ & $\begin{array}{l}0.0340 \\
(-0.21)\end{array}$ & $\begin{array}{l}-1.009 \\
(-0.31)\end{array}$ \\
\hline$B O D \_S I Z E$ & $\begin{array}{l}0.0018 \\
(0.05)\end{array}$ & $\begin{array}{l}-0.0058 \\
(-0.15)\end{array}$ & $\begin{array}{l}0.0411 \\
(0.31)\end{array}$ \\
\hline $\begin{array}{l}\text { Number of Instruments } \\
\text { Number of Observations }\end{array}$ & $\begin{array}{l}37 \\
3127\end{array}$ & $\begin{array}{l}37 \\
1686\end{array}$ & $\begin{array}{l}37 \\
1442\end{array}$ \\
\hline AR(1) test ( $p$ value) & 0.088 & 0.076 & 0.003 \\
\hline $\operatorname{AR}(2)$ test ( $p$ value) & 0.575 & 0.966 & 0.528 \\
\hline $\begin{array}{l}\text { Hansen test of over-identification } \\
\quad \text { ( } p \text { value })\end{array}$ & 0.429 & 0.545 & 0.787 \\
\hline
\end{tabular}

(1) This table reports the results of hypothesis 1 and $2 ; * * *$, and *** denote significance at the 10,5 , and $1 \%$ levels (two-tailed), respectively; The two-step system dynamic GMM approach uses Windmeijercorrected standard errors; Lag_ABSRINV is the one lag of ABS_ABINV. Other variables are defined in Table 2

at the 5\% level. However, the coefficient of FEMALE $\times$ OVERINV $\left(\beta_{3}\right)$, the variable of interest, is negative and statistically significant $\left(\beta_{1}=-0.0276, t=-1.83\right)$ at the $10 \%$ level, suggesting that the presence of a female director moderates investment inefficiency stemming from over-investment. 
Table 8 Moderating effects of female board directors

\begin{tabular}{|c|c|}
\hline \multicolumn{2}{|c|}{ Dependent variable: $A B S \_A B I N V$} \\
\hline \multicolumn{2}{|l|}{ Variables } \\
\hline Intercept & $\begin{array}{l}0.0328 \\
(0.80)\end{array}$ \\
\hline FEMALE & $\begin{array}{l}-0.0082 \\
(-0.68)\end{array}$ \\
\hline OVERINV & $\begin{array}{l}0.0127 * * \\
(2.26)\end{array}$ \\
\hline$F E M A L E \times O V E R I N V$ & $\begin{array}{l}-0.0276^{*} \\
(-1.83)\end{array}$ \\
\hline$S I Z E$ & $\begin{array}{l}-0.0005 \\
(-0.28)\end{array}$ \\
\hline$M B$ & $\begin{array}{l}-0.0024 \\
(-0.87)\end{array}$ \\
\hline$L E V$ & $\begin{array}{l}0.0023 \\
(1.04)\end{array}$ \\
\hline FreeCF & $\begin{array}{l}-0.0199 \\
(-0.88)\end{array}$ \\
\hline CFO_SALE & $\begin{array}{l}0.0666^{*} \\
(1.77)\end{array}$ \\
\hline$R O A$ & $\begin{array}{l}0.0203 \\
(0.50)\end{array}$ \\
\hline$S D \_C F O$ & $\begin{array}{l}-0.0980 \\
(-1.20)\end{array}$ \\
\hline$S D \_S A L E$ & $\begin{array}{l}0.0223 \\
(1.07)\end{array}$ \\
\hline$S D \_I N V$ & $\begin{array}{l}0.0493 * * \\
(2.39)\end{array}$ \\
\hline TANGIBILITY & $\begin{array}{l}-0.0549 * * * \\
(-3.79)\end{array}$ \\
\hline$A G E$ & $\begin{array}{l}-0.0040 \\
(-0.71)\end{array}$ \\
\hline BOD_SIZE & $\begin{array}{l}0.0085 \\
(1.11)\end{array}$ \\
\hline Year fixed effect & Included \\
\hline Industry fixed effect & Included \\
\hline $\operatorname{Adj} \_R^{2}$ & 0.2495 \\
\hline Observations & 3748 \\
\hline
\end{tabular}

This table reports the results of the moderation effects of female directors where "FEMALE $\times O V E R I N V$ " is the moderating variable; $*$, **, and *** denote significance at the 10,5 , and $1 \%$ levels (twotailed), respectively; standard errors are adjusted for firm-clustering (one-way clustering); other variables are defined in Table 2

\section{The multinomial logistic model}

Next, throughout our tests, we have assumed that the relationship between female directors and investment efficiency is linear. However, this may be a strict 
assumption. Hence, we re-examine our findings by additionally applying a multinomial logistic model similar to that used in Biddle et al. (2009) to address this issue. We do so by initially dividing our observations into quartiles based on the magnitude of the residuals from Eq. (1), after which we use these groups as the dependent variables. More specifically, we categorize firm-year observations with the most negative residuals in the bottom quartile into the under-investing group and firm-year observations with the most positive residuals in the top quartile into the over-investing group. Firm-year observations placed in the middle two quartiles are classified as the benchmark group. Then, we conduct a multinomial logit regression on two separate subsamples. The first subsample group consists of the top quartile and the middle two quartiles ("Over-Investment and benchmark"), and the second subsample group consists of the bottom quartile and the middle two quartiles ("Under-Investment and benchmark"). Therefore, each multinomial logit regression model predicts the likelihood of a firm's investment to be included in one of the extreme quartiles. We limit our analysis to firms with at least ten observations by year and industry.

Table 9 presents the results of the multinomial logistic regression based on subsamples of the OVER- and UNDER-investment. Consistent with our prior analyses, a significantly negative association between FEMALE and over-investment $\left(\beta_{1}=-0.2137, t=-1.73\right)$ is found at the $10 \%$ level in the OVER-Investment subsample, whereas this association is insignificant in the UNDER-Investment subsample. Hence, our multinomial logistic regression results again provide support for our second hypothesis that female board participation is instrumental in curbing overinvestments rather than under-investments.

\section{Other robustness tests}

We conduct several other robustness tests which include pre-post-tests, an additional alternative model, and tests excluding chaebol firms from the full sample to lend further support to our previous analyses. All results and explanations are reported in Appendix.

\section{Discussion and conclusion}

Women around the world have made significant strides in elevating their status up the corporate ladder and eventually into the boardroom, predominantly run by allmale directors. Continuing this global phenomenon, Korean business women are also gradually finding their ways into the boardroom, reflecting the wave of change in female corporate status, even in Korea's male-dominant society. Nowadays, corporate Korea is also seeing a rise in the proportion of female directors earning board seats as well as seeing their roles expand into a broader set of corporate activities (The Ministry of Gender Equality and Family 2016). Motivated by this phenomenon, our study first sets out to examine whether the presence of women executives with board seats is positively associated with investment efficiency. Then, 
Table 9 Multinomial logistic regressions using subsamples of the over-and under-investment groups

\begin{tabular}{|c|c|c|}
\hline \multicolumn{3}{|c|}{ Dependent variable: $A B S \_A B I N V$} \\
\hline Variables & $\begin{array}{l}\text { (1) } \\
\text { Over-investment and } \\
\text { benchmark group }\end{array}$ & $\begin{array}{l}\text { (2) } \\
\text { Under-investment } \\
\text { and benchmark } \\
\text { group }\end{array}$ \\
\hline Intercept & $\begin{array}{l}-0.3960 \\
(-0.58)\end{array}$ & $\begin{array}{l}-0.4859 \\
(-0.83)\end{array}$ \\
\hline FEMALE & $\begin{array}{l}-0.2137^{*} \\
(-1.73)\end{array}$ & $\begin{array}{l}-0.1001 \\
(-0.88)\end{array}$ \\
\hline SIZE & $\begin{array}{l}0.0083 \\
(0.31)\end{array}$ & $\begin{array}{l}-0.0159 \\
(-0.70)\end{array}$ \\
\hline$M B$ & $\begin{array}{l}0.0210 \\
(0.51)\end{array}$ & $\begin{array}{l}-0.0283 \\
(-0.72)\end{array}$ \\
\hline$L E V$ & $\begin{array}{l}0.0008 \\
(0.03)\end{array}$ & $\begin{array}{l}0.0239 \\
(0.85)\end{array}$ \\
\hline Free CF & $\begin{array}{l}0.0609 \\
(0.26)\end{array}$ & $\begin{array}{l}-0.3188 \\
(-1.53)\end{array}$ \\
\hline$C F O \_S A L E$ & $\begin{array}{l}0.0668 \\
(0.33)\end{array}$ & $\begin{array}{l}0.6001 * * * \\
(3.24)\end{array}$ \\
\hline$R O A$ & $\begin{array}{l}0.2882 \\
(0.57)\end{array}$ & $\begin{array}{l}0.2150 \\
(0.48)\end{array}$ \\
\hline$S D \_C F O$ & $\begin{array}{l}0.5955 \\
(0.68)\end{array}$ & $\begin{array}{l}2.5076^{* * * *} \\
(3.65)\end{array}$ \\
\hline$S D \_S A L E$ & $\begin{array}{l}-0.3049 \\
(-1.57)\end{array}$ & $\begin{array}{l}-0.2640 \\
(-1.54)\end{array}$ \\
\hline$S D \_I N V$ & $\begin{array}{l}0.6513 * * * \\
(3.66)\end{array}$ & $\begin{array}{l}0.0703 \\
(0.55)\end{array}$ \\
\hline TANGIBILITY & $\begin{array}{l}-0.1020 \\
(-0.47)\end{array}$ & $\begin{array}{l}-0.4488^{* * *} \\
(-2.26)\end{array}$ \\
\hline$A G E$ & $\begin{array}{l}-0.2601 * * * \\
(-4.24)\end{array}$ & $\begin{array}{l}-0.0235 \\
(-0.40)\end{array}$ \\
\hline BOD_SIZE & $\begin{array}{l}0.1145 \\
(1.18)\end{array}$ & $\begin{array}{l}0.1362 \\
(1.43)\end{array}$ \\
\hline Year fixed effect & Included & Included \\
\hline Industry fixed effect & Included & Included \\
\hline Max-rescaled $R^{2}$ & 0.0340 & 0.0196 \\
\hline Observations & 2522 & 2501 \\
\hline
\end{tabular}

This table reports the results of the multinomial logistic regressions in subsamples classified as over- or under-investment; *, **, and *** denote significance at the 10,5, and 1\% levels (two-tailed), respectively; standard errors are adjusted for firm-clustering (one-way clustering); all variables are defined in Table 2

we explore whether certain characteristics, i.e., risk-aversion and conservatism, of female board director(s) alter the direction of suboptimal investment decisions.

Our empirical results support the following. First, we find that female directors serving on corporate boards are associated with investment efficiency in publicly traded firms in Korea. Second, having established such an association, we further 
explore the direction of improvement by bifurcating the sample into firms that are more prone to over-invest and those more prone to under-invest. We find that this positive relationship between female board presence and investment efficiency is driven by the fact that female board members are instrumental in curbing inefficiency at firms that are more likely to over-invest, thereby improving investment efficiency. However, we do not find such a significantly positive relationship at firms that are likely to under-invest. We believe that these findings are consistent with the risk-averse hypothesis, which reflects the impact of female directors' conservatism and risk-aversion on corporate outcomes (Cohn et al. 1975; Riley and Chow 1992; Powell and Ansic 1997; Eckel and Grossman 2008; Croson and Gneezy 2009; Charness and Gneezy 2012). In addition, we provide some evidence that female directors as members of the board have the potential to strengthen the board's monitoring and advising role as well as the potential to exert a positive influence on important investment decisions in favor of shareholders, consistent with prior work (Gul et al. 2008; Adams and Ferreira 2009; Gul et al. 2011; Srinidhi et al. 2011). Specifically, in an additional analysis using annualized stock returns, we find that investments at firms with female board appointments are associated with positive future market performance, which indicates that the market appreciates and responds favorably to the expertise, business acumen, experience, and resources that these executives bring to their corporate boards. This result somewhat echoes the conclusion reached by Siegel et al. (2011), who studied the performance of multinational firms. They find that multinational firms with a higher proportion of female managers operating in Korea experience better firm performance.

Our results hold in the main analysis using the McNichols and Stubben (2008) model, the Heckman (1979) two-stage model that controls for endogeneity, and the two-step system dynamic generalized method of moment (GMM) approach that controls for reverse causality. In addition, we apply moderating effects of female board participation and adopt a multinomial logistic model similar to that in Biddle et al. (2009) to relax the assumption of linearity, which again corroborates our main results. To buttress our empirical findings further, we conduct a battery of robustness checks which include adopting a future performance model, employing a pre- and post-test of newly hired female board directors, using an alternative model incorporating forward-looking measures, and lastly excluding chaebol firms to remove the effects of these conglomerates. All of these tests provide consistent results that female directorship is associated with investment efficiency and improvements are found especially at firms more inclined to over-invest.

\section{Theoretical and policy implications}

Currently, Korea is seeing a gradual increase in the proportion of female directors entering the board room. They are wielding more power in important business decisions and garnering more attention as they assume the role of directors as well. Thus far, previous research has analyzed differences in gender based on social, sexual, attitudinal, cognitive ability, and on decision-making (Johnson and Powell 1994; Bajtelsmit and Bernasek 1996; Barber and Odean 2001; Han and Kim 2007). As 
literature illustrates, men and women interact differently based on the environments and circumstances they encounter, and preconceived stereotypical images may also manifest differently in those instances.

Carter et al. (2003) find that women are more independent in their role as directors than are men and that boards with more female directors have better corporate performance. Gul et al. (2008) document that firms with at least one women director or firms with a higher proportion of female directors on the audit committee contribute to greater audit efforts and reduced levels of earnings management. Adams and Ferreira (2009) further find that a female director's appointment to the audit committee increases its effectiveness via greater monitoring. In addition, the authors find that stock price informativeness and earnings quality improved when women are assigned to the board (Gul et al. 2011; Srinidhi et al. 2011). Hence, having female directors as members of the board increases the potential of strengthening the board's monitoring and advising role and allows them to influence important business decisions.

According to prior literature in behavioral finance, a fair amount of studies suggest that women view investment-related decisions differently from men and have different risk-taking preferences as well (Cohn et al. 1975; Bajtelsmit and Bernasek 1996; Riley and Chow 1992; Powell and Ansic 1997; Graham et al. 2002; Eckel and Grossman 2008; Croson and Gneezy 2009; Charness and Gneezy 2012). This implies that gender differences exist with respect to financial decision-making (Schumell 1996). As such, a good deal of research has investigated the investment behavior of women but to date we are unaware of any research that has examined how women in a position of authority, specifically, how female directors as board members, affect investment efficiency using Korean data. Based on literature, this study examines how certain characteristics of females, i.e., risk-aversion and conservatism, affect the financial decision-making process with regard to investment efficiency. In particular, we examine the association between female directorship and how it affects over- and under-investment decisions.

This study makes the following contributions. First, we extend the corporate governance literature on board characteristics using feminist theories, psychology, and the behavioral finance literature to explore the different implications of genderrelated characteristics on investment behavior.

Second, the Korean business environment is distinct from advanced western economies that promote gender parity and diversity. However, the chaebol-driven economy breeds a culture that reinforces the old boy's network that hinders the advancement of qualified businesswomen, who are discriminated against in such a business culture. Therefore, finding a meaningful role for female directors even in this stringent environment for women provides important implications regarding the ongoing global phenomenon of women being competitive players in today's business environment. Using a unique set of manually collected samples of female directors who serve as board members, we provide comprehensive evidence that promoting women to the board level matters with regard to a firm's investment decisions, showing that firms with females appointed to boards engage in less over-investment and thus partially improve their investment efficiency. 
Third, our results are meaningful and important because the effect of gender on corporate outcomes is a relatively unexplored topic in Korea's capital market. Moreover, the findings here show that women can, to some extent, enhance the monitoring function of a firm's resource allocation decisions. To the best of our knowledge, this is the first study using Korean publicly traded firms to find evidence that certain female-related characteristics at the board level affect investment efficiency.

Our study provides important policy implications to investors and regulatory bodies at a critical time because the Korean government is in the process of mandating a corporate gender quota in the private sector. By providing empirical evidence that female board representation plays a potentially positive role to some degree in improving investment efficiency, this study supports the government's recent efforts to pass such a law. Drastic measures at the country level are needed to improve the status of women in Korea and further narrow the wide gap of gender inequality to levels comparable to those in OECD countries. This year again, for the seventh time in a row, the recent 2019 glass-ceiling index reports that Korea's workplace gender inequality ranked the last among OECD countries (The Economist 2019). Even advanced western economies had to impose explicit rules on employers because the level of voluntary adoption toward more balanced boards was extremely slow. As argued by Thams et al. (2018), state-level policies that promote gender parity have an important ripple effect on the attitudes, actions, and career aspirations of women by increasing the supply of better educated and more experienced women, which also increases the fraction of women serving on corporate boards. Hence, our study further speaks to the recent discussion on implementing gender quota requirements to allow Korean firms to capitalize on the benefits of female board participation and tap into a broader pool of business talent.

In addition, more effort to promote higher levels of female participation in the labor market can invigorate Korea's economic growth, which has been extremely low in recent years. In comparison to other OECD countries, Korea's female employment rate still falls considerably short of the OECD average and carries the stigma of the gender pay gap ranking the highest (OCED 2017). As Christine Lagarde, managing director at the International Monetary Fund, has stated, one impetus to bolster economic growth is to reduce the gender gap in Korea's workforce. In fact, hiring more women can boost Korea's GDP by ten percent (The Diplomat, 2016). Korea lacks an abundance of natural resources; if policies can be implemented consistent with the changes in the international landscape to engage the full potential of underused female labor, this pathway can be said to present another avenue to sustainable economic growth. In February of 2019, even Shinzo Abe, Japan's prime minister, set an explicit goal to energize Japan's economy by promoting more women in the labor force via a policy called "womenomics" (The New York Times, 2019).

\section{Limitations and future research}

Although both over-investment and/or under-investment are inefficient, we consistently do not find a meaningful result showing that women directors help reduce under-investment at firms, consistent with the risk-averse view. This can be a 
problem because under-investment may be detrimental to the firm and can reduce its potential to grow over the long run (Biddle et al. 2009). Nevertheless, we believe that this partial effect of female directors on investment efficiency is relevant to the Korean business environment, as the overall investment efficiency of Korea has been deteriorating for more than a decade, mainly due to over-investment (Choi and Kwak 2010).

In addition, the separation of ownership and control does not quite apply to the complex chaebol-driven ownership structure in which chaebol family members reserve the ultimate decision rights with regard to corporate investments. Due to this unique corporate environment, obviously there is no reason to believe that chaebol owners and family members will select the best set of investment projects that maximizes firm value in the long run. Instead, they may engage in empire building, which may not be in the best interest of shareholders as well (Yim et al. 2014). To distinguish the effects of chaebols, we exclude them and find that the tenor of our results remains unchanged. That is, female board presentation is associated with investment efficiency, and the presence of a female helps to reduce over-investment again. Hence, whether discussing Korean chaebols or not, overall we believe that female characteristics, due to the risk-aversion and conservatism of females, improve investment efficiency at firms that are more prone to over-invest.

We acknowledge that under- or over-investment is also a matter of relativity and that a symmetric reduction on both sides is a better option for firms (McNichols and Stubben 2008; Biddle et al. 2009). Thus, we cannot rule out the possibility that excessive risk-aversion or conservatism viewed as a negative characteristic trait of females could lead to an asymmetric reduction in inefficient investments, only mitigating over-investment and not under-investment (Ahern and Dittmar 2012; Gregory-Smith et al. 2014; Haslam et al. 2010; Matsa and Miller 2013). Because the Korean government is encouraging more female board participation and more data will be available over time, we leave this topic of whether women board directors can also improve under-investment decisions, a more asymmetric reduction in inefficiency, for future research.

\section{Compliance with ethical standards}

Conflict of interest On behalf of all authors, the corresponding author states that there are no conflicts of interest.

Open Access This article is distributed under the terms of the Creative Commons Attribution 4.0 International License (http://creativecommons.org/licenses/by/4.0/), which permits unrestricted use, distribution, and reproduction in any medium, provided you give appropriate credit to the original author(s) and the source, provide a link to the Creative Commons license, and indicate if changes were made. 


\section{Appendix 1: Female board directors and positive market outcomes}

To provide evidence that female board directors exert a positive influence on investment decisions, we examine whether investments at firms with female directorship generate positive outcomes in terms of future market performance. The above analysis reports the results. Following Shaw et al. (2016), we use $R E T U R N_{t+1}$ as

Table 10 Female board directors and future market performance

\begin{tabular}{|c|c|}
\hline Dependent variable: $R E T U R N_{t+1}$ & \\
\hline \multicolumn{2}{|l|}{ Variables } \\
\hline Intercept & $\begin{array}{l}-0.0076^{* * * *} \\
(-13.53)\end{array}$ \\
\hline FEMALE & $\begin{array}{l}-0.0001 \\
(-0.43)\end{array}$ \\
\hline INVEST & $\begin{array}{l}0.0001 \\
(0.39)\end{array}$ \\
\hline$F E M A L E \times I N V E S T$ & $\begin{array}{l}0.0007 * * * \\
(2.85)\end{array}$ \\
\hline SIZE_ASSET & $\begin{array}{l}0.0003 * * * \\
(10.59)\end{array}$ \\
\hline$L E V$ & $\begin{array}{l}-0.0002 * * * \\
(-4.93)\end{array}$ \\
\hline$M T B$ & $\begin{array}{l}-0.0001 * * * \\
(-2.70)\end{array}$ \\
\hline$R O A$ & $\begin{array}{l}0.0064 * * * \\
(9.41)\end{array}$ \\
\hline$A G E$ & $\begin{array}{l}-0.0001 \\
(-1.46)\end{array}$ \\
\hline BOD_SIZE & $\begin{array}{l}0.0001 \\
(-0.25)\end{array}$ \\
\hline Year fixed effect & Included \\
\hline Industry fixed effect & Included \\
\hline Adj_R $R^{2}$ & 0.2494 \\
\hline Observations & 3671 \\
\hline
\end{tabular}

This table reports the results of the effect of female board directors and market performance; $*, * *$, and $* * *$ denote significance at the 10, 5, and 1\% levels (two-tailed), respectively; standard errors are adjusted for firm-clustering (one-way clustering); INVEST is the increases in capital expenditures from the statement of cash flows/ beginning of year total assets; RETURN ${ }_{t+1}$ is a firm's future performance measured as using the firm's 12 month annualized stock returns; all other variables are defined in Table 2 
the dependent variable, which represents a firm's future performance as measured using the firm's twelve-month annualized stock returns. All other variables are as defined previously. As shown above, the coefficient of the interaction term of FEMALE $\times O V E R I N V$ is significantly positive at the $1 \%$ level after controlling for other various factors that affect efficiency. This result is more revealing, indicating that women board directors are able to exert a positive influence on a firm's investment decisions and hence investment efficiency.

\section{Appendix 2: Pre- and post-test for newly hired female board directors and investment efficiency}

\section{Pre-post tests on hiring female directors}

In the Korean business environment, the separation of ownership and control is not quite applicable due to the chaebol-driven conglomerates, where family members reserve the ultimate power with regard to management decisions. Hence, members of the board in corporate Korea have continued to receive criticism over their monitoring and advising roles. An awareness of this fact raises the possibility that the conclusions reached in this study may be skeptical in the eyes of the reader. Therefore, we also attempt to apply a pre- and post-test which controls for other conditions to analyze whether a change in efficiency occurs at firms that newly appoint at least one female director(s) as an additional robustness check. We do so using a subsample of firms with newly hired female directors that initially did not have such a director and determine whether a change in efficiency is observed thereafter. If a positive change in investment efficiency manifests as a result of hiring a new female board member vis-à-vis before such recruitment, even after controlling for various factors that affect efficiency, this result will reveal more that women board directors are able to exert a positive influence on a firm's investment decisions and hence investment efficiency.

Table 11 reports the results of the pre- and post-test using a subsample of firms with female director representation. The variable of interest is FEMALE_POST, which takes on a value of 1 in the year and subsequent years the firm hires at least one women director as a board member and 0 otherwise. The analysis shows that the coefficient of FEMALE_POST $\left(\beta_{1}\right)$ is negative and statistically significant $\left(\beta_{1}=-0.0455, t=-1.74\right)$ at the $10 \%$ level which suggests that inviting a female director to a firm's board does improve investment efficiency.

In sum, we believe that this approach will help diffuse reservations about our study to some degree and bolster our previous empirical predictions and results as shown in the tables on the topic of female board participation and investment efficiency. 
Table 11 Pre- and post-test

\begin{tabular}{ll}
\hline Dependent variable: $A B S \_A B I N V$ & \\
\hline Variables & \\
Intercept & $-0.0800(-0.61)$ \\
FEMALE_POST & $-0.0455^{*}(-1.74)$ \\
SIZE & $-0.0018(-0.26)$ \\
$M B$ & $0.0050(0.64)$ \\
$L E V$ & $0.0085(1.53)$ \\
FreeCF & $-0.0404(-0.43)$ \\
$C F O \_S A L E$ & $0.0315(0.78)$ \\
ROA & $0.1856(1.11)$ \\
$S D \_C F O$ & $0.0869(0.35)$ \\
$S D \_S A L E$ & $0.1051(1.24)$ \\
$S D \_I N V$ & $0.0065(0.12)$ \\
$T A N G I B I L I T Y$ & $-0.0984(-1.59)$ \\
$A G E$ & $0.0420(1.48)$ \\
BOD_SIZE & $-0.0050(-0.14)$ \\
Adj_R $R^{2}$ & 0.261 \\
Observations & 372 \\
\hline
\end{tabular}

This table reports the result of the pre-and post-test for hypothesis 1 using only the Female group; *, **, and *** denote significance at the 10,5, and $1 \%$ levels (two-tailed), respectively; standard errors are adjusted for firm-clustering (one-way clustering); Female_Post is a dummy variable that equals 1 if year $t$ falls in the period subsequent to the year when a female director is appointed, 0 otherwise; Other variables are defined in Table 2

\section{Appendix 3: Additional analysis using an alternative model}

We used a model that captures the optimal level of investment based on past estimates. However, because the optimal level of investment imputed from the past may deviate significantly from the expected level due to unexpected changes within the industry or due to macroeconomic conditions, in this section we adopt a different model that is more forward-looking by re-examining the association between the possibility of over-investment in the current year $\left(O V E R_{i, t}\right)$ and the actual amounts these firms invested in the next period $\left(C A P E X_{i, t+1}\right)$. Specifically, as described in Eq. (4), we estimate a firm's over-investment to test whether female directors are able to leverage their influence by lowering the amounts in capital investment at firms more prone to exhibit greater levels of over-investment following the model by Biddle et al. (2009). In conducting this analysis, we drop observations when merging $C A P E X_{i, t+1}$, which captures estimates of the future period with other control variables, when re-examining Eq. (4), and drop as well observations with missing values. This reduces the number of observations to a sample of 3196. We report these results in Table 12. 
Table 12 Additional analysis using an alternative model

\begin{tabular}{|c|c|}
\hline \multicolumn{2}{|c|}{ Dependent variable: $C A P E X$} \\
\hline \multicolumn{2}{|l|}{ Variables } \\
\hline Intercept & $41.438 * * *(3.63)$ \\
\hline FEMALE & $1.162(1.12)$ \\
\hline$F E M A L E^{*} O V E R$ & $-4.023 * *(-2.02)$ \\
\hline OVER & $-0.693(-0.61)$ \\
\hline$M B$ & $1.408 * * *(2.90)$ \\
\hline$A G E$ & $-0.874(-1.37)$ \\
\hline$D I V$ & $33.014(0.85)$ \\
\hline$M V$ & $0.388(1.48)$ \\
\hline ZSCORE & $0.021(1.40)$ \\
\hline CFO_SALE & $2.357(0.66)$ \\
\hline$N I$ & $2.203(0.45)$ \\
\hline TANGIBILITY & $-11.801 * * *(-5.10)$ \\
\hline OPER_CYCLE & $0.717(1.41)$ \\
\hline$S D \_C F O$ & $1.248 * * *(3.69)$ \\
\hline$S D \_S A L E$ & $-0.100(-0.04)$ \\
\hline$S D \_I N V$ & $12.336 * * *(3.26)$ \\
\hline$M E A N \_K$ & $-138.009 * * *(-4.25)$ \\
\hline BOD_SIZE & $-1.001(-1009)$ \\
\hline Year fixed effect & Included \\
\hline Industry fixed effect & Included \\
\hline $\operatorname{Adj} \_R^{2}$ & 0.1544 \\
\hline Observations & 3196 \\
\hline
\end{tabular}

This table reports the result of hypothesis 1 using an alternative model adopted in Biddle et al. (2009); *, **, and *** denote significance at the 10,5 , and $1 \%$ levels (two-tailed), respectively; Standard errors are adjusted by firm-clustering (one-way clustering); Variable definitions: CAPEX is the (Cash outflows for capital expenditure/lagged property, plant, and equipment) $\times 100$; OVER is the Dummy variable that equals 1 , if the quartile rank of both $C E$ and LEVERAGE belongs to the highest rank, 0 otherwise; $C E$ is the Cash and cash equivalent/total assets; LEVERAGE is the (Total debt/ total assets) $\times$ ' -1 '; DIV is the Cash dividends/lagged total assets; $M V$ is the natural log value of market capitalization; ZSCORE is the Altman's Z score, modified by MacKie-Mason (1990); NI is the net income/lagged total assets; OPER_CYCLE is the natural log value of the sum of (i) the average number of days that inventories are held and (ii) the average number of days that accounting receivables are held; $M E A N \_K$ is the industry mean value of long-term debt/market capitalization; Other variables are defined in Table 2

$$
\begin{aligned}
\text { CAPEX }_{i, t+1}= & \beta_{0}+\beta_{1} \text { FEMALE }_{i, t}+\beta_{2} \text { FEMALE } \times \text { OVER }_{i, t}+\beta_{3} \text { OVER }_{i, t} \\
& +\sum_{(k=1)}^{(k=17)} \beta_{k} \text { Controls }+ \text { YEAR, IND }+\omega_{i, t}
\end{aligned}
$$

In these equations, the following are defined: 
CAPEX is the (cash outflows for capital expenditure/lagged property, plant, and equipment) $\times 100, O V E R$ is the a dummy variable that equals 1 if the quartile rank of both $C E$ and $L E V E R A G E$ belongs to the highest rank, and 0 otherwise, $C E$ is the cash and cash equivalents/total assets, LEVERAGE is the (total debts/total assets) $\times$ ' -1 ', $D I V$ is the cash dividends/lagged total assets, $M V$ is the the natural logarithm of market capitalization, ZSCORE is the Altman's Z score, modified by MacKie-Mason (1990), NI is the net income/lagged total assets, OPER_CYCLE is the the natural logarithm of the sum of (i) the average number of days that inventories are held and (ii) the average number of days that accounting receivables are held, Mean_K is the the industry mean value of long-term debt divided by market capitalization, Other variables is the identical to those addressed in Table 2.

We define firms that are likely to over-invest following prior studies (Biddle et al. 2009; Yim et al. 2014), where we sort firms into quartiles based on the magnitude of cash and cash equivalents scaled by total assets $(C E)$ and on leverage scaled by total assets multiplied by ' -1 ' (LEVERAGE). Firms with the highest $C E$ and LEVERAGE scores are assigned to the top quartile, which represents firms' tendency to over-invest. ${ }^{\mathbf{5}}$ We use $C A P E X_{t+1}$, which represents capital investment in the next period, in our regression with a new set of control variables that affects subsequent capital investment. If firms tend to make inefficient capital investment decisions, we expect a positive relationship between $O V E R$ and $C A P E X_{t+1}$, which means that cash-rich firms with lower levels of debt are apt to invest in negative (-) NPV projects, giving rise to over-investment (Yim et al. 2014).

Table 12 reports the regression results of the alternative model with regard to investment efficiency. Here, the coefficient $\left(\beta_{2}\right)$ on the interaction term between FEMALE and OVER represents the relationship between the magnitude of CAPEX in year $t+1$ and the possibility of over-investment in year $t$ for firms that have female directors. Accordingly, our variable of interest is the coefficient $\left(\beta_{2}\right)$. More specifically, to support our main analyses, the sign of the coefficient, $\beta_{2}$, should be significantly negative, suggesting that female directors play a significant role in reducing future capital expenditures, especially where the possibility of over-investment is expected to be higher. Our results indicate that the coefficient $\beta_{2}$ is -4.023 , which is statistically significant at the $5 \%$ level $(t$ value $=-2.02)$. This result implies that firms with female board members are less likely to over-invest despite the fact that they have a greater ability to do so, thereby improving investment efficiency. In other words, the conclusion reached with this alternative model also corroborates our previous findings.

\section{Appendix 4: Additional analysis excluding chaebol firms}

Family members of chaebol-driven conglomerates have the final say on important corporate investment decisions, where the separation of ownership and control is not quite applicable to Korea's unique business environment. Thus, it is important to make a distinction between the effects of female directors (family members) of chaebol firms and those of other firms. Hence, we re-examine our hypotheses while excluding chaebol firms from our sample. Table 13 above provides empirical results that are consistent with the main findings. 
Table 13 Cross-sectional regressions: full sample and subsamples excluding chaebol firms

\begin{tabular}{|c|c|c|c|}
\hline Variables & $\begin{array}{l}(1) \\
\text { Full sample }\end{array}$ & $\begin{array}{l}\text { (2) } \\
\text { Over-investment }\end{array}$ & $\begin{array}{l}\text { (3) } \\
\text { Under-investment }\end{array}$ \\
\hline Intercept & $\begin{array}{l}0.0395 \\
(0.66)\end{array}$ & $\begin{array}{l}0.2262 * * \\
(2.42)\end{array}$ & $\begin{array}{l}-0.1247 \\
(-1.38)\end{array}$ \\
\hline FEMALE & $\begin{array}{l}-0.0242^{* *} \\
(-2.55)\end{array}$ & $\begin{array}{l}-0.0414 * * * \\
(-2.94)\end{array}$ & $\begin{array}{l}-0.0082 \\
(-0.58)\end{array}$ \\
\hline$S I Z E$ & $\begin{array}{l}0.0004 \\
(0.13)\end{array}$ & $\begin{array}{l}-0.0064^{*} \\
(-1.70)\end{array}$ & $\begin{array}{l}0.0062 \\
(1.62)\end{array}$ \\
\hline$M B$ & $\begin{array}{l}-0.0039 \\
(-1.08)\end{array}$ & $\begin{array}{l}0.0061 \\
(0.98)\end{array}$ & $\begin{array}{l}-0.0132 * * \\
(-2.48)\end{array}$ \\
\hline$L E V$ & $\begin{array}{l}0.0025 \\
(0.93)\end{array}$ & $\begin{array}{l}-0.0015 \\
(-0.35)\end{array}$ & $\begin{array}{l}0.0047 \\
(1.15)\end{array}$ \\
\hline Free $C F$ & $\begin{array}{l}-0.0146 \\
(-0.62)\end{array}$ & $\begin{array}{l}-0.0400 \\
(-1.21)\end{array}$ & $\begin{array}{l}-0.0003 \\
(-0.01)\end{array}$ \\
\hline CFO_SALE & $\begin{array}{l}0.0420 \\
(1.08)\end{array}$ & $\begin{array}{l}0.0583 \\
(0.85)\end{array}$ & $\begin{array}{l}0.0147 \\
(0.31)\end{array}$ \\
\hline$R O A$ & $\begin{array}{l}0.0027 \\
(0.07)\end{array}$ & $\begin{array}{l}-0.0136 \\
(-0.22)\end{array}$ & $\begin{array}{l}0.0222 \\
(0.38)\end{array}$ \\
\hline$S D \_C F O$ & $\begin{array}{l}-0.0368 \\
(-0.46)\end{array}$ & $\begin{array}{l}-0.1060 \\
(-0.81)\end{array}$ & $\begin{array}{l}0.0271 \\
(0.29)\end{array}$ \\
\hline$S D \_S A L E$ & $\begin{array}{l}0.0025 \\
(0.12)\end{array}$ & $\begin{array}{l}0.0083 \\
(0.22)\end{array}$ & $\begin{array}{l}0.0064 \\
(0.24)\end{array}$ \\
\hline$S D \_I N V$ & $\begin{array}{l}0.0360 * * \\
(2.00)\end{array}$ & $\begin{array}{l}0.0803 * * * \\
(3.50)\end{array}$ & $\begin{array}{l}-0.0066 \\
(-0.40)\end{array}$ \\
\hline TANGIBILITY & $\begin{array}{l}-0.0539 * * * \\
(-3.35)\end{array}$ & $\begin{array}{l}-0.0493^{*} \\
(-1.73)\end{array}$ & $\begin{array}{l}-0.0578 * * * \\
(-2.92)\end{array}$ \\
\hline$A G E$ & $\begin{array}{l}-0.0060 \\
(-0.97)\end{array}$ & $\begin{array}{l}-0.0161^{*} \\
(-1.74)\end{array}$ & $\begin{array}{l}0.0033 \\
(0.39)\end{array}$ \\
\hline BOD_SIZE & $\begin{array}{l}0.0113 \\
(1.37)\end{array}$ & $\begin{array}{l}0.0150 \\
(1.06)\end{array}$ & $\begin{array}{l}0.0086 \\
(0.75)\end{array}$ \\
\hline Year fixed effect & Included & Included & Included \\
\hline Industry fixed effect & Included & Included & Included \\
\hline $\operatorname{Adj} \_R^{2}$ & 0.2626 & 0.2851 & 0.2392 \\
\hline Observations & 3053 & 1410 & 1623 \\
\hline
\end{tabular}

This table reports the results of hypothesis 1 and $2 ; * * * *$, and *** denote significance at the 10,5 , and $1 \%$ levels (two-tailed), respectively; standard errors are adjusted for firm-clustering (one-way clustering); all variables are defined in Table 2

\section{References}

Abbott, L. J., Parker, S., \& Presley, T. J. (2012). Female board presence and the likelihood of financial restatement. Accounting Horizons, 26(4), 607-629.

Adams, R. B. (2016). Women on boards: The superheroes of tomorrow? The Leadership Quarterly, 27(3), 371-386.

Adams, R. B., \& Ferreira, D. (2009). Women in the boardroom and their impact on governance and performance. Journal of Financial Economics, 94(2), 291-309. 
Ahern, K. R., \& Dittmar, A. K. (2012). The changing of the boards: The impact on firm valuation of mandated female board representation. The Quarterly Journal of Economics, 127(1), 137-197.

Arráiz, I. (2018). Time to share the load: gender differences in household responsibilities and business profitability. Small Business Economics, 51(1), 57-84.

Bader, A. K., Kemper, L. E., \& Froese, F. J. (2018). Who promotes a value-in-diversity perspective? A fuzzy set analysis of executives' individual and organizational characteristics. Human Resource Management, 58(2), 203-217.

Bae, G. S., \& Choi, S. U. (2012). Do industry specialist auditors improve investment efficiency? SSRN Working Paper. Retrieved February 26, 2019, from http://dx.doi.org/10.2139/ssrn.2145191.

Bajtelsmit, V. L., \& Bernasek, A. (1996). Why do women invest differently than men? Journal of Financial Counseling and Planning Education, 7, 1-10.

Barber, B. M., \& Odean, T. (2001). Boys will be boys: Gender, overconfidence, and common stock investment. The Quarterly Journal of Economics, 116(1), 261-292.

Barua, A., Davidson, L. F., Rama, D. V., \& Thiruvadi, S. (2010). CFO gender and accruals quality. Accounting Horizons, 24(1), 25-39.

Beasley, M. S. (1996). An empirical analysis of the relation between the board of director composition and financial statement fraud. Accounting Review, 71(4), 443-465.

Berger, A. N., Kick, T., \& Schaeck, K. (2014). Executive board composition and bank risk taking. Journal of Corporate Finance, 28, 48-65.

Biddle, G. C., \& Hilary, G. (2006). Accounting quality and firm-level capital investment. The Accounting Review, 81(5), 963-982.

Biddle, G. C., Hilary, G., \& Verdi, R. S. (2009). How does financial reporting quality relate to investment efficiency? Journal of Accounting and Economics, 48(2), 112-131.

Black, N. (1989). Social feminism. New York: Cornell University Press.

Booth, A. L., \& Nolen, P. (2012). Gender differences in risk behaviour: Does nurture matter? The Economic Journal, 122(558), F56-F78.

Bosma, N., Van Praag, M., Thurik, R., \& De Wit, G. (2004). The value of human and social capital investments for the business performance of startups. Small Business Economics, 23(3), 227-236.

Brinkhuis, E., \& Scholtens, B. (2018). Investor response to appointment of female CEOs and CFOs. The Leadership Quarterly, 29(3), 423-441.

Byun, Y. H. (2005). An analysis of the effect of investor gender and overconfidence on trading volume and performance. Korean Journal of Applied Economics, 7(30), 37-65.

CalPERS. (2017, August 22). CalPERS expands engagement for greater diversity on corporate boards to more than 500 U.S. companies. Press Release. Retrieved from https://www.calpers.ca.gov/page/ newsroom/calpers-news/2017/engagement-corporate-board-diversity.

Carter, S., \& Rosa, P. (1998). Indigenous rural firms: Farm enterprises in the UK. International Small Business Journal, 16(4), 15-27.

Carter, D. A., Simkins, B. J., \& Simpson, W. G. (2003). Corporate governance, board diversity, and firm value. Financial Review, 38(1), 33-53.

Charness, G., \& Gneezy, U. (2012). Strong evidence for gender differences in risk taking. Journal of Economic Behavior, 83(1), 50-58.

Charreaux, G., \& Desbrières, P. (1998). Gouvernance Des Entreprises: Valeur Partenariale Contre Valeur Actionnariale. Finance Contrôle Stratégie, 1(2), 57-88.

Chen, J., Leung, W. S., \& Goergen, M. (2017). The impact of board gender composition on dividend payouts. Journal of Corporate Finance, 43, 86-105.

Cheng, M., Dhaliwal, D., \& Zhang, Y. (2013). Does investment efficiency improve after the disclosure of material weaknesses in internal control over financial reporting? Journal of Accounting and Economics, 56(1), 1-18.

Choi, J. S., \& Kwak, Y. M. (2010). Association between managerial overinvestment propensity and real and accrual-based earnings management. Korean Accounting Review, 35(4), 75-131.

Chung, C. Y., Cho, S. J., Ryu, D., \& Ryu, D. (2019). Institutional blockholders and corporate social responsibility. Asian Business \& Management. https://doi.org/10.1057/s41291-018-00056-w.

Cohn, R. A., Lewellen, W. G., Lease, R. C., \& Schlarbaum, G. G. (1975). Individual investor risk aversion and investment portfolio composition. The Journal of Finance, 30(2), 605-620.

Conyon, M. J., \& He, L. (2017). Firm performance and boardroom gender diversity: A quantile regression approach. Journal of Business Research, 79, 198-211.

Cooper, A. C., Gimeno-Gascon, F. J., \& Woo, C. Y. (1994). Initial human and financial capital as predictors of new venture performance. Journal of Business Venturing, 9(5), 371-395. 
Croson, R., \& Gneezy, U. (2009). Gender differences in preferences. Journal of Economic Literature, 47(2), 448-474.

Doo, S. Y., Han, S. S., \& Song, K. S. (2016). An empirical study on the relation among firm life cycle, market competition, and investment efficiency. Korean Accounting Journal, 25(4), 209-225.

Du Rietz, A., \& Henrekson, M. (2000). Testing the female underperformance hypothesis. Small Business Economics, 14(1), 1-10.

Eckel, C. C., \& Grossman, P. J. (2008). Men, women and risk aversion: Experimental evidence. In C. Plott \& V. Smith (Eds.), Handbook of experimental economics results (Vol. 1, pp. 1061-1073). New York: Elsevier.

Faccio, M., Marchica, M. T., \& Mura, R. (2016). CEO gender, corporate risk-taking, and the efficiency of capital allocation. Journal of Corporate Finance, 39, 193-209.

Fischer, E. M., Reuber, A. R., \& Dyke, L. S. (1993). A theoretical overview and extension of research on sex, gender, and entrepreneurship. Journal of Business Venturing, 8, 151-168.

Geiler, P., \& Renneboog, L. (2015). Are female top managers really paid less? Journal of Corporate Finance, 35, 345-369.

Graham, J. F., Stendardi, E. J., Jr., Myers, J. K., \& Graham, M. J. (2002). Gender Differences in Investment Strategies: An Information Processing Perspective. International Journal of Bank Marketing, 20(1), 17-26.

Green, C. P., \& Homroy, S. (2018). Female directors, board committees and firm performance. European Economic Review, 102, 19-38.

Gregory-Smith, I., Main, B. G., \& O'Reilly, C. A., III. (2014). Appointments, pay and performance in UK boardrooms by gender. The Economic Journal, 124(574), F109-F128.

Gul, F., Srinidhi, B., \& Ng, A. (2011). Does board gender diversity improve the informativeness of stock prices? Journal of Accounting and Economics, 51(3), 314-338.

Gul, F. A., Srinidhi, B. \& Tsui, J. S. (2008). Board diversity and the demand for higher audit effort. SSRN Working Paper. Retrieved February 26, 2019, from http://dx.doi.org/10.2139/ssrn.1359450.

Gull, A. A., Nekhili, M., Nagati, H., \& Chtioui, T. (2018). Beyond gender diversity: How specific attributes of female directors affect earnings management. The British Accounting Review, 50(3), 255-274.

Han, M. Y., \& Kim, J. H. (2007). The effect of self-enhancement perception and confidence of investment of individual investors on risky investment behaviors. The Korean Journal of Culture and Social Issues, 13(3), 89-109.

Harford, J. (1999). Corporate cash reserves and acquisitions. The Journal of Finance, 54(6), 1969-1997.

Haslam, S. A., Ryan, M. K., Kulich, C., Trojanowski, G., \& Atkins, C. (2010). Investing with prejudice: The relationship between women's presence on company boards and objective and subjective measures of company performance. British Journal of Management, 21(2), 484-497.

Heckman, J. J. (1979). Sample selection bias as a specification error. Econometrica, 47(1), 153-161.

Hillman, A. J., Shropshire, C., \& Cannella, A. A. (2007). Organizational predictors of women on corporate boards. Academy of Management Journal, 50(4), 941-952.

Holmes, M. (2007). What is gender?. Sociological approaches: Sage.

Huang, J., \& Kisgen, D. J. (2013). Gender and corporate finance: are male executives overconfident relative to female executives? Journal of Financial Economics, 108(3), 822-839.

Hundley, G. (2001). Why women earn less than men in self-employment. Journal of Labor Research, 22(4), 817-829.

Jensen, M. C. (1986). Agency costs of free cash flow, corporate finance, and takeovers. The American Economic Review, 76(2), 323-329.

Jeon, K. M., Shin, Y., \& Kim, H. (2017). Board diversity and real earnings management. Korean Accounting Review, 26(3), 33-77.

Johnson, J. E., \& Powell, P. L. (1994). Decision making, risk and gender: Are managers different? British Journal of Management, 5(2), 123-138.

Jung, D. M. (2002). Differences between men and women of accounting information process. Korean Accounting Information Research, 18, 211-227.

Kang, H., Cheng, M., \& Gray, S. J. (2007). Corporate governance and board composition: Diversity and independence of Australian boards. Corporate Governance: An International Review, 15(2), 194-207.

Kim, B. H. (2006). The influence of the board composition on earnings management in Korean firmsLooking at cases of upwards and downwards management. Korean Accounting Review, 31(1), $1-32$. 
Kim, J. O., \& Bae, G. S. (2007). Corporate governance and accounting conservatism: Evidence from board and audit committee characteristics. Korean Accounting Review, 32(2), 89-115.

Kim, S., \& Hong, J. (2015). The effects of the number of female directors on the board to corporate transparency. Korea International Accounting Review, 56, 69-100.

Kim, H. A., Jeong, S. W., Kang, T., \& Lee, D. (2017). Does the presence of female executives curb earnings management? Evidence from Korea. Australian Accounting Review, 27(4), 494-506.

Kim, Y., \& Oh, O. O. (2017). The effect of the ratio of female executives and staff members and female employee's tenure on the relevance of stock price. Journal of Taxation and Accounting, 18(4), 173-193.

Klapper, L. F., \& Parker, S. C. (2010). Gender and the business environment for new firm creation. The World Bank Research Observer, 26(2), 237-257.

Klein, A. (2002). Audit committee, board of director characteristics, and earnings management. Journal of Accounting and Economics, 33(3), 375-400.

Kulich, C., Trojanowski, G., Ryan, M. K., Alexander Haslam, S., \& Renneboog, L. D. (2011). Who gets the carrot and who gets the stick? Evidence of gender disparities in executive remuneration. Strategic Management, 32(3), 301-321.

Levi, M., Li, K., \& Zhang, F. (2014). Director gender and mergers and acquisitions. Journal of Corporate Finance, 28, 185-200.

Liu, Y., Wei, Z., \& Xie, F. (2014). Do women directors improve firm performance in China? Journal of Corporate Finance, 28, 169-184.

MacKie-Mason, J. K. (1990). Do taxes affect corporate financing decisions? The Journal of Finance, 45(5), 1471-1493.

Marlow, S., \& Patton, D. (2005). All credit to men? Entrepreneurship, finance, and gender. Entrepreneurship Theory and Practice, 29(6), 717-735.

Matsa, D. A., \& Miller, A. R. (2013). A female style in corporate leadership? Evidence from quotas. American Economic Journal: Applied Economics, 5(3), 136-169.

McAdam, M. (2013). Female entrepreneurship. London: Routledge.

McNichols, M. F., \& Stubben, S. R. (2008). Does earnings management affect firms' investment decisions? The Accounting Review, 83(6), 1571-1603.

Milliken, F. J., \& Martins, L. L. (1996). Searching for common threads: Understanding the multiple effects of diversity in organizational groups. Academy of Management Review, 21(2), 402-433.

Modigliani, F., \& Miller, M. H. (1958). The cost of capital, corporation finance and the theory of investment. The American Economic Review, 48(3), 261-297.

MSCI. (2016). The tipping point-Women on boards and financial performance. Retrieved from https:// www.msci.com/www/research-paper/the-tipping-point-women-on/0538947986.

Mukarram, S. S., Saeed, A., Hammoudeh, S., \& Raziq, M. M. (2018). Women on Indian boards and market performance: A role-congruity theory perspective. Asian Business \& Management, 17(1), 4-36.

Mukhtar, S. M. (2002). Differences in male and female management characteristics: A study of ownermanager businesses. Small Business Economics, 18(4), 289-310.

Ng, J. C. Y., Huang, M. M. D., \& Liu, Y. (2016). The 'feminine' entrepreneurial personality trait: The competitive advantage of female college-student entrepreneurs in Chinese Wei-Shang businesses? Asian Business \& Management, 15(5), 343-369.

Nini, G., Smith, D. C., \& Sufi, A. (2009). Creditor control rights and firm investment policy. Journal of Financial Economics, 92(3), 400-420.

OCED. (2017). The pursuit of gender equality: An uphill battle. Retrieved from https://www.oecd.org/ korea/Gender2017-KOR-en.pdf.

Owen, A. L., \& Temesvary, J. (2018). The performance effects of gender diversity on bank boards. Journal of Banking \& Finance, 90, 50-63.

Palvia, A., Vähämaa, E., \& Vähämaa, S. (2015). Are female CEOs and chairwomen more conservative and risk averse? Evidence from the banking industry during the financial crisis. Journal of Business Ethics, 131(3), 577-594.

Park, J. H., \& Kwon, D. H. (2012). The impact of foreign ownership on investment efficiency. Korean Accounting Review, 37(3), 277-307.

Peretz, H., Levi, A., \& Fried, Y. (2015). Organizational diversity programs across cultures: Effects on absenteeism, turnover, performance and innovation. The International Journal of Human Resource Management, 26(6), 875-903. 
Perryman, A. A., Fernando, G. D., \& Tripathy, A. (2016). Do gender differences persist? An examination of gender diversity on firm performance, risk, and executive compensation. Journal of Business Research, 69(2), 579-586.

Post, C., \& Byron, K. (2015). Women on boards and firm financial performance: A meta-analysis. Academy of Management Journal, 58(5), 1546-1571.

Powell, M., \& Ansic, D. (1997). Gender differences in risk behaviour in financial decision-making: an experimental analysis. Journal of Economic Psychology, 18(6), 605-628.

Riley, W. B., Jr., \& Chow, K. V. (1992). Asset allocation and individual risk aversion. Financial Analysts Journal, 48(6), 32-37.

Rose, C. (2007). Does female board representation influence firm performance? The Danish evidence. Corporate Governance: An International Review, 15(2), 404-413.

Ryu, D., Ryu, D., \& Hwang, J. H. (2017). Corporate governance, product-market competition, and stock returns: Evidence from the Korean market. Asian Business \& Management, 16(1-2), 50-91.

Schumell, D. G. (1996). Trust marketing: Increased focus on women as financial service consumers. Trusts and Estates-Atlanta, 135, 19-21.

Shaw, T. S., Cordeiro, J. J., \& Saravanan, P. (2016). Director network resources and firm performance: Evidence from Indian corporate governance reforms. Asian Business \& Management, 15(3), $165-200$.

Shawn, H., \& Jung, J. G. (2013). Research articles: The effect of auditor gender on audit quality and conservatism. Korean Accounting Review, 38(2), 327-364.

Siegel, J. I., Kodama, N., \& Halaburda, H. (2014). The unfairness trap: A key missing factor in the economic theory of discrimination. Harvard Business School Strategy Unit Working Paper No. 13-082. Retrieved February 26, 2019, from http://dx.doi.org/10.2139/ssrn.2390078.

Siegel, J., Pyun, L., \& Cheon, B. Y. (2011). Multinational firms, labor market discrimination, and the capture of outsider's advantage by exploiting the social divide. Administrative Science Quarterly, 41, 1-28.

Sila, V., Gonzalez, A., \& Hagendorff, J. (2016). Women on board: Does boardroom gender diversity affect firm risk? Journal of Corporate Finance, 36, 26-53.

Simga-Mugan, C., Daly, B. A., Onkal, D., \& Kavut, L. (2005). The influence of nationality and gender on ethical sensitivity: An application of the issue-contingent model. Journal of Business Ethics, 57(2), 139-159.

Srinidhi, B., Gul, F. A., \& Tsui, J. (2011). Female directors and earnings quality. Contemporary Accounting Research, 28(5), 1610-1644.

Stoermer, S., Bader, A. K., \& Froese, F. J. (2016). Culture matters: The influence of national culture on inclusion climate. Cross Cultural \& Strategic Management, 23(2), 287-305.

Strohmeyer, R., Tonoyan, V., \& Jennings, J. E. (2017). Jacks-(and Jills)-of-all-trades: On whether, how and why gender influences firm innovativeness. Journal of Business Venturing, 32(5), 498-518.

Thams, Y., Bendell, B. L., \& Terjesen, S. (2018). Explaining women's presence on corporate boards: The institutionalization of progressive gender-related policies. Journal of Business Research, 86, 130-140.

The Diplomat. (2016, March 16). Asia's boards: Where are the women? Retrieved from https://thedi plomat.com/2016/03/asias-boards-where-are-the-women/.

The Economist. (2019). The glass-ceiling index. Retrieved from https://www.economist.com/graphicdetail/2019/03/08/the-glass-ceiling-index.

The Ministry of Gender Equality and Family. (2016). Women corporate directors at the top 100 companies increased $41 \%$ over three years. Retrieved from http://www.mogef.go.kr/nw/rpd/nw_rpd_ s001d.do?mid=news405\&bbtSn=703376.

The New York Times. (2019, February 2). Japan needs moms in the workplace, but many are stuck in limited roles as they shoulder most of the burden at home-with little help from dads. Retrieved from https://www.nytimes.com/2019/02/02/world/asia/japan-working-mothers.html.

Tobin, J. (1969). A general equilibrium approach to monetary theory. Journal of Money, Credit and Banking, 1(1), 29.

Vafeas, N. (2000). Board structure and the informativeness of earnings. Journal of Accounting and Public Policy, 19(2), 139-160.

Verdi, R. S. (2006). Financial reporting quality and investment efficiency. SSRN Working Paper. Retrieved February 26, 2019, from http://dx.doi.org/10.2139/ssrn.930922.

Wahn, J. (2003). Sex differences in competitive and compliant unethical work behavior. Journal of Business and Psychology, 18(1), 121-128. 
World Bank. (2018). The World Bank in Republic of Korea. Retrieved from http://www.worldbank.org/ en/country/korea/overview.

Xie, B., Davison, W. N., \& DaDalt, P. J. (2003). Earnings management and corporate governance: The role of the board and the audit committee. Journal of Corporate Finance, 9(3), 295-316.

Yim, S. G., Lee, M. Y., \& Hwang, I. Y. (2014). The investment efficiency of firms belonging to large business conglomerates. Korean Accounting Review, 39(3), 91-134.

Publisher's Note Springer Nature remains neutral with regard to jurisdictional claims in published maps and institutional affiliations. 